\title{
Mi a téma? Politikai témák és felhasználói reakciók szövegbányászati vizsgálata a 2018-as országgyưlési kampány politikusi Facebook-oldalain ${ }^{1}$
}

\author{
BENE MÁRTON²
}

\begin{abstract}
ABSZTRAKT
A tanulmány szövegbányászati eszközökkel vizsgálja, hogy a felhasználók hogyan reagálnak a 2018-as magyarországi országgyúlési választás kampányának vezetői témáira a jelöltek Facebook-oldalain. Azt feltételezi, hogy a kiemelt (migráció, korrupció) és a kampánnyal kapcsolatos posztok több reakciót váltanak ki, míg a közpolitikai témák és a mobilizációs tartalmak kevésbé lesznek népszerúek. Mindezek túlmenően a témagazda-hatás elméletet is teszteli a felhasználói reaktivitás tekintetében. E feltevéseket egy olyan adatbázison teszteli a kutatás, amely a választás minden mérhető támogatottságú jelöltjének a kampány alatt közzétett összes posztját tartalmazza (511 jelölt 38030 posztja), a témákat pedig szövegbányászati eszközökkel azonosítja, ily módon használva ki a közösségi médiában rejlő „big data”-elemzés lehetőségét. Az eredmények azt mutatják, hogy a korrupció, a fejlesztéspolitika és a kampány a legnépszerübb témák a Facebookon, míg a migráció csak az ellenzéki politikusok oldalán volt vonzó, a kormánypárti politikusok követői kerülték a migrációs témájú posztokra való reagálását. A legérdekesebb eredmény a fordított témagazda-hatáshoz kapcsolódik, miszerint a politikusok saját témáikkal általában kevésbé tudnak reakciókat kiváltani, mint ellenfeleik ugyanezekben a témákban.
\end{abstract}

KULCSSZAVAK: közösségi média, témagazda-hatás, migráció, felhasználói reakciók, szövegbányászat

\section{ABSTRACT}

What's the matter? A text mining analysis of political topics and user engagement on politicians' Facebook pages during the 2018 Hungarian general election campaign

The research investigates the way users interact with leading topics of the 2018 Hungarian general election campaign on candidates' Facebook pages. It expects that the prominent (immigration, corruption) and campaign-related topics generate more user engagement, while

${ }^{1}$ A tanulmány az Innovációs és Technológiai Minisztérium ÚNKP-21-5 kódszámú Új Nemzeti Kiválóság Programjának a Nemzeti Kutatási, Fejlesztési és Innovációs Alapból finanszírozott szakmai támogatásával készült (ÚNKP-21-5-ELTE-1094). A tanulmány angol nyelvű változata a Journal of Information Technology \& Politics folyóiratban jelent meg.

${ }^{2}$ Társadalomtudományi Kutatóközpont, ELTE ÁJK, e-mail: Bene.Marton@tk.hu 


\section{TEMATIKUS TANULMÁNYOK - Digitális szociológia}

policy topics and mobilization contentare lessinteracted. It also tests the theory of issue ownership in relation with user engagement. These expectations are tested on a dataset that includes all posts (38030 posts) posted by all candidates during the campaign (511 candidates). Topics are identified by text mining methods. The study demonstrates that corruption, development policy and campaign are highly engaged topics, while immigration was more interacted only on opposition politicians' pages since the followers of pro-government candidates engage less with immigration-related content. The most surprising result is that a reversed issue ownership effect can be detected since politicians are generally less successful with their own topics.

KEYWORDS: social media, issue ownership, immigration, user engagement, text mining

\section{Bevezetés}

Az elmúlt néhány év fontos fejleménye, hogy az állampolgárok online kommunikációs aktivitása a politikai kommunikációs ökoszisztéma ütőerévé vált (Blumler 2016). Míg korábban a politikai szereplők kommunikációjukat az állampolgárok kognitív és affektív szükségleteire szabták, ma már az emberek egymás közötti politikai társalgásait is célba veszik. Mivel az állampolgárok közösségi média aktivitása képes a politikai üzeneteket széles körben láthatóvá tenni, ezért a politikusok kommunikációja mindinkább alkalmazkodik a felhasználókéhoz, e folyamat pedig a politika 'viralizációjának' fogalmával ragadható meg (Bene 2020). Emiatt fontos megértenünk az állampolgárok politikai tartalmakkal folytatott interakcióit a közösségi médiában, mivel e mintázatok jelentős hatással vannak a politikai szereplők kommunikációjára (Ennser-Jedenastik et al. 2021).

Egyre kiterjedtebb szakirodalom foglalkozik azzal, hogy a közösségi média felhasználók a politikai szereplők milyen típusú tartalmaira reagálnak (Bene 2020, Heiss et al 2019, Keller - Kleinen-von Königslöw 2018, Štětka et al 2019, Xenos et al. 2017). E kutatás azonban a szakirodalom két még mindig meglévő hiányosságát próbálja pótolni a 2018-as magyarországi országgyűlési kampány vizsgálatán keresztül. Először is, még mindig nagyon korlátozott a tudásunk arról, hogy milyen típusú politikai tématerületek váltanak ki felhasználói reakciókat. Tekintve, hogy a politikai kommunikáció-kutatás milyen jelentőséget tulajdonított korábban a politikai témák nyilvánosságban való láthatóságának (lásd, Baumgartner - Jones 1993; Iyengar et al 1982, McCombs - Shaw 1972), ez a vonatkozó irodalom egy meglepő hiányossága. A kutatás elsődleges fókusza ezért arra irányul, hogy a kampány legfontosabb témái a jelöltek Facebook-oldalain milyen mértékben tudtak felhasználói reakciókat kiváltani. Azt feltételezi, hogy a leginkább kiemelt (migráció, korrupció), illetve a kampányhoz szorosan kapcsolódó témák a legsikeresebbek ebben a tekintetben, miközben a hagyományos közpolitikai ügyek, illetve a mobilizációs kísérletek kevésbé népszerűek. Mivel az egyes témák általában erősen kötődnek adott politikai szereplőkhöz, ezért a kutatás azt is megvizsgálja, hogy a témagazda-elmélet (issue 


\section{TEMATIKUS TANULMÁNYOK - Digitális szociológia}

ownership theory) (Petrocik 1996) mennyiben képes magyarázni a felhasználói reaktivitás mintázatait.

A második hiányosság abból fakad, hogy a létező kutatások nem használják ki a közösségi oldalak „big data”-potenciálját. A vonatkozó vizsgálatok rendszerint manuálisan gyüjtött adatokra támaszkodnak, ez pedig mintavételi döntéseket igényel, ami gyengíti az eredmények külső érvényességét, általánosíthatóságát. E kutatás szótár- és felügyelt gépi tanulási módszerekre támaszkodó szövegbányászati eszközökkel dolgozza fel az adatokat, így a Facebook tartalmak teljes populációja figyelembe vehető. Ezért a hipotéziseket egy egyedülállóan kiterjedt adatbázison teszteli, amely 511 jelölt a kampány hét hete alatt közzétett több mint 38030 ezer posztját tartalmazza.

\section{Elméleti keret}

\section{A POLITIKAI KOMMUNIKÁCIÓ „VIRALIZÁCIÓJA”}

A politikai szereplők kommunikációs erőfeszítéseinek célja a szavazók politikai attitûdjeire és magatartására való hatásgyakorlás. A hatás eléréséhez azonban a kommunikációnak csatornákra van szüksége. A 20. század végéig a politikai szereplők könnyen hozzáfértek a kommunikációs csatornákhoz, egyrészt amiatt, mert a tömegmédia a politikát a nyilvános élet egy kiemelt, önjogán tudósításra érdemes szférájaként kezelte („sacerdotal approaches to politics”, lásd, Blumler 1965:98105), másrészt pedig azért mert a pártok maguk is nagyszámú csatornát birtokoltak vagy kontrolláltak (újságok, aktivista hálózatok stb.). A politikai kommunikáció a 20. század végén kezdődő, úgynevezett „harmadik korszakától” (Blumler - Kavanagh 1999) kezdve azonban a csatornákhoz való hozzáférés egyre nagyobb kihívássá vált a politikai szereplők számára, ugyanis a sokcsatornás médiatérben a közönség egyre inkább fragmentálódott, és a mindinkább kereskedelmi logika által irányított tömegmédiában a politika elvesztette kiemelt szerepét.

Az információbőség e kontextusában a politikusoknak meg kell küzdeniük a korábban magától értetődő figyelemért egymással, illetve minden egyéb, akár teljesen más területen tevékenykedő tartalomtermelővel (Coleman - Blumler 2009). A politikai szereplők nézőpontjából ez azt jelenti, hogy politikai üzeneteikkel már nem csak a választókat kell megcélozniuk, hanem az üzenetet közvetítendő csatornák figyelmét is meg kell, hogy ragadják kommunikációjukkal.

A célpont megkettőződése a politikai kommunikáció működésére is hatással van. A szakirodalom már kiterjedten dokumentálta, hogy a politikai kommunikáció hogyan változott meg amiatt, hogy a politikai szereplők üzeneteiket egyre inkább a professzionális média kereskedelmi logikájához igazítják annak érdekében, hogy 


\section{TEMATIKUS TANULMÁNYOK - Digitális szociológia}

láthatóságukat növeljék (Lundby 2009). A kutatók e folyamatot a „politika mediatizációjának" nevezték el (Strömbäck 2008).

A közösségi oldalak, különösen az utóbbi években kiemelt politikai információforrássá váló Facebook, a politikai szereplők számára alternatív csatornákat kínálnak a választók elérésére. A Facebookon a tartalomterjedés domináns logikája a viralitás (Klinger - Svensson 2015), hiszen a felhasználók nyilvánosan látható interakciói a posztokkal (Reakciók, ${ }^{3}$ kommentek és megosztások) képesek az eredeti üzenetet széles körben elterjeszteni. Ezek az interakciók egyfelől megjelenhetnek az ismerősök hírvonalán, így azok is láthatják az adott politikai szereplő posztját, akik őt egyébként nem követik. Ráadásul ily módon e tartalmakat saját ismerőseik közvetítésén és ajánlásán keresztül érzékelik, ami növelheti azok hitelességének (Turcotte et al. 2015) vagy relevanciájának érzetét (Anspach 2017). Másfelől, a hírvonalakon megjelenő tartalmakat algoritmusok szűrik, és bár a Facebook titokban tartja az algoritmus múködésének pontos szempontrendszerét, az közismert, hogy a több interaktivitást kiváltó tartalmak nagyobb valószínűséggel jelennek meg a felhasználók előtt, mint a kevésbé reagált posztok (Bucher 2012).

Következésképpen a Facebookon az állampolgárok, illetve az ő reakcióik szolgáltatják azt a csatornát, amelyen keresztül az üzenet eljuttatható a választók szélesebb rétegeihez. Éppen ezért a politikusok azáltal tudnak csatornát szerezni az üzeneteikhez, ha azokkal egyúttal reakcióra is bírják a felhasználókat (Bene 2020). Kutatások bizonyították, hogy a politikusok közösségi média kommunikációjának valóban egyik legfontosabb célja a felhasználói reakciók kiváltása (Bene - Somodi 2018, Kelm 2020). Ezért aktívan monitorozzák a felhasználók interakciós igényeit (McGregor 2020), és igyekeznek ezekhez igazítani kommunikációjukat (Barberá et al. 2019, Ennser-Jedenastik et al. 2021). Ráadásul azt is tudjuk, hogy a felhasználói reakciók kiváltása hatással van a választási teljesítményre (Bene 2020), illetve a professzionális médiában való láthatóságra is (Kruikemeier et al. 2018). Ahogyan azonban a professzionális média reakcióira való hatásgyakorlás célja átalakította a politikai kommunikáció formáját és tartalmát, úgy az is okkal feltételezhető, hogy amikor egy másfajta logikához, az állampolgári kommunikáció logikájához igazodnak a politikai szereplők, akkor az is jelentős változásokat eredményez. E folyamatra, mely során a politikusok a közösségi média virális terjedési logikájához igazodnak, a mediatizáció analógiájára a politikai kommunikáció 'viralizációjaként' hivatkozhatunk (Bene 2020). Ezért érdemes feltárni, hogy miben is áll ez az átalakulás.

Elméleti szempontból legalább két olyan érv is felhozható, amelyek miatt a politika viralizációja jelentős változásokat eredményezhet a politikai kommunikáció működésében. Először is, a politikai kommunikáció célja ezidáig alapvetően a vá-

${ }^{3}$ Az általános kommunikációs válaszként felfogott reakció, és a Facebookon a lájkolást is magába foglaló, de további hangulati válaszelemekkel kiegészített reakciógombok közötti különbségtétel érdekében utóbbiakat nagybetűvel írom a szövegben. 


\section{TEMATIKUS TANULMÁNYOK - Digitális szociológia}

lasztók kognitív és affektív kapacitásaira való hatásgyakorlás volt, az állampolgárokat elsődlegesen „nézőközönségként” („spectators”) kezelték, akiket meggyőzni, lenyűgözni, szórakoztatni és érzelmileg felfokozott állapotban tartani kell (Coleman Blumler 2009). Ezzel szemben a közösségi médiában a hatékony kommunikációnak az állampolgárok - a politikai kommunikáció tömegmédia-központú működése által nagyrészt figyelmen kívül hagyott - kommunikatív és társas természetét is célba kell vennie, és a nézőközönséget résztvevőkké kell változtatnia (Kreiss 2016: 5). Másodszor, okkal feltételezhető, hogy az állampolgárok máshogy reagálnak a politikai tartalmakra, mint a professzionális médiatermékek. A média kommunikációját kereskedelmi érdekek, professzionális normák, vagy éppen politikai szempontok irányítják (lásd: Strömbäck - Esser 2014), ezért e faktorok határozzák meg, hogy az újságírók milyen politikai üzenetekre reagálnak. Ezzel szemben a választók politikai kommunikációját a közösségi oldalakon elsődlegesen expresszív motivációk vezérlik, ami azt jelenti, hogy kommunikációjuk során személyes identitásukat jelenítik meg és formálják erős és gyenge kapcsolataik előtt (Bennett - Segerber 2013, Svensson 2011). Az eltérő motivációk feltehetően különböző kommunikációs mintázatokat eredményeznek, ezért várhatóan különböző politikai tartalmak is illeszkednek ezekhez. Annak megállapításához, hogy ez a gyakorlatban mit is jelent, empirikus vizsgálatokra van szükség.

\section{Felhasználói reaktivitás a politikai szereplők Facebook-oldalain}

Csak a legutóbbi években kezdték el részletesebben vizsgálni, hogy az állampolgárok milyen tartalmakkal lépnek interakcióba a politikai szereplők oldalain (lásd: Bene 2020, Heiss et al. 2019, Keller - Kleinein-von Königslöw 2018, Xenos et al. 2017). Bár az eredmények meglehetősen vegyesek, a meglévő kutatások számos tartalmi faktor állampolgári reakciókra gyakorolt hatását vizsgálták. A növekvő számú kutatás ellenére két lényeges hiányosság megmaradt. Az első hiányosság tartalmi jellegú. Miközben a posztok formájának, retorikájának, érzelmi és stilisztikai jegyeinek valamint politikai keretezésének hatásairól egyre többet tudunk, a téma kérdése jóval kisebb figyelmet kapott. Miközben az eredmények megmutatták, hogy a szöveges (Bene 2020), moralizáló (Sahly et al. 2019), negatív (Bene 2020, Heiss et al. 2019), meglepő (Staender et al. 2019) és a páthosz retorikai eszközét (Gerodimos Justinussen 2015, Heiss et al. 2019) alkalmazó posztok jobban terjednek a Facebookon, jóval korlátozottabb a tudásunk arról, hogy milyen politikai témákkal lépnek leginkább interakcióba a felhasználók.

A téma dimenziójának figyelmen kívül hagyása azért is meglepő, mert a politikai kommunikáció-kutatás a múltban nagy jelentőséget tulajdonított annak, hogy milyen topikok terjednek jól a mediatizált kommunikációs szférában. Számos médiahatás elmélet amellett érvelt ugyanis, hogy a tömegmédia azáltal tudja alakítani 


\section{TEMATIKUS TANULMÁNYOK - Digitális szociológia}

a politikai folyamatokat, hogy egyes témákra erőteljesebben fókuszál, míg másokat figyelmen kívül hagy. A napirend-elmélet szerint a tömegmédiában erősen jelenlévő témák lesznek azok, amelyeket a választók fontosnak tartanak (McCombs - Shaw 1972). A priming-elmélet is azt hangsúlyozza, hogy a tömegmédia a témákon keresztül hat a választóra, azonban ez a megközelítés az állampolgárok politikai értékelési folyamataira fókuszál, és úgy látja, hogy e kiemelt témák ebben válnak meghatározóvá (Iyengar et al. 1982). A megszakított egyensúly elmélet a média közpolitikai dinamikában játszott szerepére koncentrál, és azt állítja, hogy a média egyes témákon való erőteljes fókusza „közpolitikai ablakokat” (policy window) nyithat, amelyeken keresztül jelentős, a hagyományos közpolitikai dinamikától idegen mértékű közpolitikai változások mehetnek végbe (Baumgarner - Jones 1993, Boda - Sebők 2018). Összefoglalva tehát, ezek az elméletek mind arra mutatnak rá, hogy a média a tematikus agendáján keresztül tudja leginkább formálni a politikai folyamatokat. A közösségi médiában azonban a napirendet főként a felhasználói interaktivitás mintázatai határozzák meg, ezért szükséges azonosítani azokat a témákat, amelyekkel előszeretettel interaktálnak a felhasználók. A tárgyalt elméletek alapján ugyanis e témák lesznek hatással a választók szélesebb tömegeinek politikai viselkedésére és a politikai folyamatokra.

A második hiányosság módszertani természetű. A vonatkozó kutatások manuálisan kódolták adataikat annak érdekében, hogy a politikai szereplők kommunikációjának felhasználói reaktivitásra gyakorolt hatásait feltárják. A kézi kódolás magas belső érvényességű adatokat eredményez, ugyanakkor erőforrásigényes volta miatt mintavételi döntéseket is szükségessé tesz, ami korlátozhatja az eredmények általánosíthatóságát (Guo et al. 2016). A legtöbb tanulmány ezért csak kisszámú politikai szereplőre fókuszál, ahol az eredményeket erősen torzíthatják a kiválasztott szereplők vagy követői bázisuk egyéni sajátosságai (lásd: Gerodimos - Justinussen 2015, Sahly et al. 2019, Staender et al. 2019, Štětka et al. 2019). Miközben ezek a tanulmányok alkalmasak arra, hogy azonosítsák egy-egy kulcsszerepet játszó politikai szereplő kommunikációjának lényeges aspektusait és hatásait, a felhasználói reaktivitás általánosabb mintázatairól nem szolgáltatnak tudással. Jóval kevesebb kutatás vizsgálja ezt a kérdést nagyobb mintán, ami lehetővé teszi az eredmények megfigyeléseken túli általánosítását (lásd: Bene 2020, Heiss et al. 2019, Keller - Kleinen-von Königslö 2018, Xenos et al. 2017), de ezekben az esetekben más jellegű mintavételi döntéseket kell meghozni a kutatóknak (például: rövidebb időszak, legsikeresebb posztok), hogy a kézi kódoláson alapuló adatgyűjtés kivitelezhető maradjon. Minden bizonnyal ezek a mintavételi torzítások állnak a gyakran egymásnak is ellentmondó eredmények mögött.

A közösségi oldalak és az egyre fejlettebb és elérhetőbb automatizált szövegfeldolgozási módszerek lehetővé teszik azonban, hogy minden releváns adatot bevonjunk a kutatásba, leküzdve ezáltal a mintavételi döntésekből fakadó korlátokat (Guo et al. 2016, Sebők 2016). Az egész kiterjedt populációt lefedő „big data” teljes 


\section{TEMATIKUS TANULMÁNYOK - Digitális szociológia}

vizsgálata könnyebben általánosítható eredményeket produkálhat. Természetesen számos olyan szempont is megjelenik az irodalomban, melyeket meglehetősen nehéz szövegbányászati módszerekkel megragadni (például retorika, stílus), így ezek magas érvényességű vizsgálata továbbra is kézi kódolást igényel. A politikai témák szókincse azonban rendszerint erősebben elválik egymástól, ezért a szótár alapú és felügyelt gépi tanuláson alapuló módszerek alkalmasak lehetnek ezek azonosítására. E kutatás ezért a mintavételi döntésekből fakadó torzítások kiküszöbölésére törekszik azáltal, hogy a kutatási kérdést egy kiterjedt, a politikai aktorok és posztjaik teljes populációját lefedő adatbázis automatizált feldolgozásán keresztül kísérli megválaszolni.

Mindezek alapján e kutatás kérdése a következő: Milyen politikai témák váltanak ki felhasználói reakciókat a politikai szereplők Facebook-oldalain?

\section{Hipotézisek}

A kampány során számtalan téma bukkan fel a politikusok kommunikációjában. E kutatás a 2018-as magyarországi választási kampány legfontosabb témáinak a reaktivitásra gyakorolt hatásait vizsgálja. A kampányokban rendszerint nagy hangsúlyt kapnak bizonyos, közérdeklődésre számot tartó ügyek. A kutatás ezek közül a kampány két legkiemeltebb ügyének, a migrációnak és a korrupciónak, illetve a három leginkább megjelenített hagyományos közpolitikai témájának, az egészségügynek, az oktatásnak és a fejlesztéspolitikának a hatásait vizsgálja. Mivel ezek a témák általában erősen kötődnek bizonyos politikai szereplőkhöz, ezért a kutatás azt is teszteli, hogy a témagazda-hipotézis érvényes-e a felhasználói reaktivitás esetében. E specifikusabb ügyeken kívül mivel maga a kampány, annak eseményei és az ahhoz kapcsolódó mobilizációs erőfeszítések minden választás előtt kiemelt témák, ezért ezek felhasználói interakciókra gyakorolt hatásait is vizsgálja a kutatás.

A 2018-as kampányt két téma dominálta elsődlegesen: a migráció (Bíró-Nagy 2018) és a korrupció (Kmetty 2018). A migráció a kormánypártok elsődleges témája volt, míg a korrupció az ellenzéki pártok kommunikációjában foglalt el kitüntetett helyet. A két téma leginkább szembetűnő közös vonása, hogy jelentőségük nem korlátozódik a kampányidőszakra. A migráció már 2015 óta a kormánypártok legfontosabb mobilizáló témája, és számos kampányt folytattak azóta (például nemzeti konzultáció, népszavazás, plakátkampányok) a migráció ügyére fókuszálva. Hasonlóképpen, a kormányzati szereplőkkel szembeni korrupciós vádak már 2010 óta visszatérőek az ellenzéki oldalon, és több mobilizációs kezdeményezés fűződik ehhez a témához is, úgy mint népszavazási aláírásgyűjtések, tüntetések, petíciók, plakátkampányok és hasonlók. E két téma természetesen nagy népszerűségnek örvend más kampánykörnyezetben is (lásd: Dolezal - Zeglovits 2014). 


\section{TEMATIKUS TANULMÁNYOK - Digitális szociológia}

Stratégiai nézőpontból lényeges kérdés, hogy a politikai szereplők által erősen nyomott témák hogyan tudnak terjedni a közösségi oldalakon. A professzionális hírmédia általában jelentős teret enged a politikai elitek kommunikációjában kiemelt témáknak (Bennett 1990). Azt azonban nem tudjuk, hogy a felhasználók is támogatják-e a politikai szereplők stratégiai elképzeléseit azzal, hogy reakcióikon keresztül felerősítik az általuk erőteljesen nyomott témák láthatóságát, vagy épphogy akadályozzák ezt azáltal, hogy figyelmen kívül hagyják az ezekre az ügyekre fókuszáló tartalmakat. Két érv szól amellett, hogy a választók reaktívak e két kiemelt ügy kapcsán a Facebookon. Először is, empirikus kutatások igazolták, hogy a migráció és a korrupció ügyének nyilvánosságbeli markáns jelenléte jelentősen befolyásolta az állampolgárok attitűdjeit és percepcióit (Bíró-Nagy 2018, Kmetty 2018), tehát a pártok általi kiemelésük erősen hatott a választók kognitív és affektív kapacitásaira. Ha az emberek azokra a posztokra reagálnak, amelyek kognitív és affektív szempontból hatással vannak rájuk (Eberl et al. 2020), akkor azt várhatjuk, hogy e témák több reakciót fognak kiváltani az oldalon. A második érv e témák sajátosságaihoz kötődik. Napjaink politikájában egyfajta populista fellendülés („populist zeitgeist" - Mudde 2004) figyelhető meg, és az emberek ma különösen fogékonyak a korrupció és migráció témáira, amelyeket még a nem populista szereplők is gyakrabban értelmeznek populista módon (Ernst et al. 2019).

H1. A migrációval és a korrupcióval foglalkozó posztok több felhasználói reakciót váltanak ki, mint más posztok.

Tradicionális közpolitikai területek is fontos témái a kampányoknak: a politikai szereplők rendszerint közpolitikai ígéreteket tesznek, illetve riválisaik közpolitikai teljesítményét és terveit bírálják. A legfontosabb közpolitikai területeket a pártok által a kampányban tett ígéretek alapján azonosítja a kutatás. Dobos és munkatársai (2018) összegyűjtötték a kampány alatt tett összes írott vagy szóban tett választási ígéretet, és azt találták, hogy a legtöbb ígéret az egészségügy (összes ígéret 8,6\%a), az iskolázottság $(7,1 \%)$ és a fejlesztéspolitika $(6,8 \%)$ területére irányult. Természetesen a politikai táborok között jelentős eltérések vannak: az ellenzéki pártok az egészségügyre és az oktatásra fókuszáltak, míg a kormánypártok első számú közpolitikai témája a fejlesztéspolitika volt.

Kutatások azt is igazolták, hogy hagyományos közpolitikai témák és érvelések kevésbé vannak jelen a politikai szereplők közösségi média kommunikációjában (Gerodimos - Justinussen 2015, Štětka et al. 2019). Miközben a közpolitikai tartalmak nyilvános kommunikációban való visszaszorulása általánosabban is jellemző napjaink politikai kommunikációjára (Coleman - Blumler 2009), a professzionális média mégis viszonylag jelentős figyelmet szentel a legfontosabb közpolitikai történéseknek. Azt feltételezhetjük, hogy a közösségi média kommunikáció esetében nem csak a közpolitikai tartalmak kínálata csökken, hanem az ilyen jellegű posztokra való igény is. A közösségi médiában zajló aktivitást jelentős részben a felhasználók expresszív motivációi vezérlik (Bennett - Segerberg 2013), hiszen minden nyilvános 


\section{TEMATIKUS TANULMÁNYOK - Digitális szociológia}

megnyilatkozásukkal saját magukat jelenítik meg teljes kiterjedt társadalmi hálózatuk előtt. Emiatt ezekre az aktivitásokra identitás-performanszként tekinthetünk, amelyeken keresztül az egyének alakítják mások róluk alkotott benyomásait (Goffman 1959, Svensson 2011). A felhasználók ezért olyan közösségi média tartalmakkal lépnek elsősorban kapcsolatba, amelyek segítenek valamit megjeleníteni saját személyes identitásukból (Ben 2020, Bennett - Segerberg 2013). Okkal érvelhetünk amellett, hogy személyes identitást kifejezni minden bizonnyal jóval nehezebb közpolitikai tartalmakon keresztül, hiszen ezek általában túl specifikusak, összetettek és bonyolultak ahhoz, hogy az egyén identitásának legfontosabb aspektusairól, értékeiről és moralitásáról üzeneteket közvetítsenek. Ráadásul a közpolitikai tartalmak jelentése általában zárt, avagy előre világosan meghatározott. Ezzel szemben a közösségi média kommunikációban a nyitottabb, sokféleképpen értelmezhető, különböző identitások kifejezésére is alkalmas tartalmak a népszerübbek (Bennett - Segerberg 2013). Mindezen okok miatt a kutatás vonatkozó hipotézise:

H2. A három kiemelt közpolitikai témával, azaz az egészségüggyel, oktatással és fejlesztéspolitikával foglalkozó posztok kevesebb felhasználói reakciót váltanak ki a politikusok Facebook-oldalain.

Az egyes ügyek azonban erősen kötődnek bizonyos pártokhoz. A témagazda-elmélet azt képviseli, hogy a pártok birtokolnak egyes témákat, amelyekben kompetensebbnek és hitelesebbnek látszanak a választók szemében (Petrocik 1996). Mivel a pártok profitálhatnak abból, ha olyan témákkal kötődnek össze, amelyek a választók számára fontosak (Ansolabehere - Iyengar 1994), a kampányban jelentős erőfeszítéseket is tesznek azért, hogy bizonyos ügyek hozzájuk kapcsolódjanak, és ezeket a választók számára is fontossá tegyék (Petrocik 1996). Ahogy arról fentebb már volt szó, a vizsgált magyar esetben is voltak témagazdák: a migráció és a fejlesztéspolitika a kormánypártokkal, míg a korrupció, az oktatás és az egészségügy az ellenzéki oldallal kötődött össze. Azt azonban nem tudjuk, hogy a politikusok követői is valóban e témákra reagálnak legszívesebben. E kérdés megválaszolásához az témagazda-elméletet a felhasználói reaktivitás vizsgálatára adoptálva a kutatás azt feltételezi:

H3. Az ügygazdák több interakciót váltanak ki saját témájukkal, mint a témát nem birtokló szereplők. Tehát a kormánypárti jelöltek migrációval és fejlesztéspolitikával, míg az ellenzéki pártok korrupcióval, oktatással és egészségüggyel kapcsolatos posztjai több felhasználói reakciót váltanak ki.

A kampány azonban nagyrészt saját magáról szól. Az üzenetek jelentős része a politikai versengéssel, a különböző kampányeseményekkel, a szavazók mobilizálásával vagy az ellenfelek támadásával foglalkozik. A választási kampányokról egyre inkább egyfajta „lóversenyként” tudósít a professzionális média, és a stratégiai, nem közpolitikai jellegű aspektusok kapnak nagyobb hangsúlyt (Banducci - Hanretty 2014). Ezáltal a választók is egyre inkább a kampányeseményekre figyelnek. Ráadásul, a kampányeseményekre fókuszáló tartalmakat jóval egyszerübb értelmezni, 


\section{TEMATIKUS TANULMÁNYOK - Digitális szociológia}

megérteni és véleményt formálni róluk, így könnyen lehet kapcsolódni hozzájuk. Emiatt az a kutatás várakozása, hogy a felhasználói reaktivitás csak még inkább felerősíti a politika „lóverseny”-jellegét, azáltal, hogy a kampány-üzeneteket teszi még szélesebb körben láthatóvá. ki.

H4. A kampánytémákkal foglalkozó posztok több felhasználói reakciót váltanak

A kampánytartalmak egy kiemelt altípusa a mobilizációs üzenetek, amelyek célja, hogy a felhasználók online figyelmét a politikai szereplők offline cselekvéssé (szavazás, offline eseményen részvétel) változtassák. Az ilyen mobilizációs üzenetekkel való interakció, különösen ezek megosztása, egyfajta politikai aktivizmusként is felfogható, hiszen ilyenkor a felhasználó célja minden bizonnyal saját ismerősei aktivitásra sarkallása. A politikai szereplőknek egyre nagyobb szükségük van az ilyen jellegű alacsony erőforrás-igényű digitális aktivizmusra, hiszen a hagyományos aktivistabázisok mérete jelentősen csökkent az elmúlt évtizedekben. Ezért érdemes vizsgálni, hogy a közösségi média az offline mobilizáció alkalmas terepének számít-e. A vonatkozó empirikus vizsgálatok eredményei azonban ellentmondásosak (lásd: Heiss et al. 2019, Štětka et al. 2019). Ugyanakkor, ahogy arról korábban már szó volt, a felhasználói aktivitás elsődlegesen expresszív motivációkkal magyarázható, míg az offline cselekvésére való felszólítást tartalmazó poszttal való interakció inkább instrumentális motivációkkal, az ismerősök politikai befolyásolásának szándékával, írható le. E kutatás azt feltételezi, hogy a felhasználói kommunikációt ezen a platformon nem politikai célok vezérlik, így a követők jelentős része nem szándékozik a kampány aktív résztvevőjévé válni.

H4a. Az offline mobilizációs üzeneteket tartalmazó posztok kevesebb felhasználói interakciót váltanak ki.

\section{Módszertan}

\section{ADATOK}

Az adatbázis a 2018-as országgyűlési kampányban képviselői helyért induló jelöltek összes Facebook-posztját tartalmazza. Azokat a jelölteket vettem figyelembe, akik vagy legalább a szavazatok 1\%-át elérték a 106 egyéni választókörzet valamelyikében vagy a 0,5\%-nál több szavazatot szerző 8 országos pártlista első 30 helyének egyikén szerepeltek. E jelöltek 83\%-a rendelkezett nyilvános Facebook-oldallal (N = 523). A választás másnapján a Facebook API-on ${ }^{4}$ keresztül töltöttem le e jelöltek öszszes, a kampány hivatalos kezdőnapjától (2018. 02.17.) a szavazóurnák zárásig

\footnotetext{
${ }^{4} \mathrm{Az}$ adatokat a Python-ra írt facebook-page-post-scraper csomag segítségével töltöttem le, lásd: https://github. com/minimaxir/facebook-page-post-scraper/blob/mas ter/README.md
} 


\section{TEMATIKUS TANULMÁNYOK - Digitális szociológia}

(2018. 04. 08., 19.00) közzétett posztját. Ez a metódus összesen 48883 posztot eredményezett 511 jelölttől ${ }^{5}$ a vizsgált 51 napos időszakból, és mivel módszerünk szövegbányászati eszközökre épül, ezek közül a 38030 szöveges tartalmat is tartalmazó poszt került a végső adatbázisba. A szöveges adatokat a feldolgozás előtt megtisztítottam, így a számok, a központozás, a ragok, a nagyon általános szavak (például: névelők, kötőszavak) és a pártok nevei (stopwords), linkek és hashtagek a szövegekből eltávolításra kerültek. ${ }^{6}$

\section{VÁLTOZÓK}

A kutatás elemzési egysége tehát az egyes Facebook-posztok, a függő változók pedig e posztok által kiváltott Reakciók (0 és 52070 között, átlag = 174; szórás = 860), kommentek (0 - 16 499, á = 15, sz = 130) és megosztások $(0-25129$, á = 43, sz = 303) száma. A független változók a posztok témái, amelyeket szövegbányászati módszerekkel azonosítottam: szótár-alapú metódust alkalmaztam a migráció, a korrupció és a közpolitikai témák detektálására, míg a kampányhoz kapcsolódó és a mobilizációra fókuszáló tartalmak jelenlétét felügyelt gépi tanulási algoritmus segítségével rögzítettem (a főbb szövegbányászati megközelítésekről lásd: Sebők 2016). Az automatizált tartalomelemzésből származó változók érvényességének ellenőrzéséhez a szövegbányászati eredményeket összevetettem egy kézileg kódolt úgynevezett „aranystandard” adatbázissal. A modellek teljesítményét a pontosság (precision), a felidézés (recall) és az F1 értékek segítségével értékeltem. A pontosság azt mutatja meg, hogy az automatizáltan azonosított elemek hány százaléka helyes, míg a felidézés arra világít rá, hogy az adott kategóriába tartozó elemek mekkora részét tudta azonosítani a szövegbányászati metódus. Az F1-érték e két mutató alapján számolható ki, mely a 0 és 1 közötti tartományba eshet, ahol az 1 az aranystandardhoz való tökéletes igazodást, az emberi kódolással megegyező pontosságot és felidézést jelenti.

1600 véletlenszerúen kiválasztott poszt lett manuálisan is kódolva, ami egyszerre szolgált a szótár-alapú módszer értékeléséhez szükséges aranystandardként, és a felügyelt gépi tanulás tanító halmazaként (training set). További véletlenszerűen kiválasztott 400 kézzel rögzített poszt a felügyelt gépi tanulási algoritmus teljesítményének értékeléséhez használt aranystandardként szolgált. ${ }^{7}$ A kódoló nem ismer-

${ }^{5} 12$ olyan jelölt volt, akiknek a posztjait nem lehetett az API-on keresztül letölteni, ezért a végső adatbázis 511 jelöltet tartalmaz.

${ }^{6}$ Ehhez az R-re írt 'tm' csomagot alkalmaztam (Feinerer et al. 2008).

${ }^{7}$ Az adatokat Burai Krisztina kódolta. A kézi kódolás megbízhatóságának ellenőrzésére a tanulmány szerzője is lekódolt 250 posztot a mintából, ez alapján pedig kiszámítható a Krippendorff's alpha értéke, amely minden kategória esetén megfelelő szintet mutatott (migráció $=.82$, korrupció =.81, egészségügy = .90 , oktatás $=.79$, fejlesztéspolitika = .85, kampány =.74, mobilizáció =.87. 


\section{TEMATIKUS TANULMÁNYOK - Digitális szociológia}

te a témák azonosítására használt szótárakat, ezért a kézi kódolás független volt a szövegbányászati megközelítéstől. ${ }^{8}$

A témák szótáralapú azonosítására minden témához össze kellett állítani egy témaspecifikus szótárat. A szótár elemeinek kiválasztásánál két fő szempontot kellett érvényesíteni: egyrészt a kiválasztott szavak és szókapcsolatok valamelyikének a témához kapcsolódó posztok nagy többségében meg kell jelennie (magas szintű felidézés), másrészt a kiválasztott elemek csak elvétve bukkanjanak fel olyan posztokban, amelyek nem érintik az adott témát (magas szintű pontosság). Szerencsére a politikai ügyek általában eléggé specifikus szókinccsel rendelkeznek, ezért lehetséges olyan szavakat és szókapcsolatokat találni, amelyek (1) nagyon jellemzőek egy adott témára; (2) és kizárólag az adott téma kapcsán bukkannak fel (Eberl et al. 2020).

A szótár-összeállítás induktív és deduktív elemeket egyaránt tartalmazó iteratív folyamat eredménye volt (hasonló megközelítésért lásd Muddiman et al. 2019). Első lépében intuitív alapon meghatároztam egy-egy témaspecifikus kulcsszót, úgy mint az „oktatás” és az „egyetem” az oktatáspolitika, illetve a „korrupt” a korrupció témánál. Ezt követően az adatbázist leszűkítettem azokra a posztokra, amelyek e kulcsszavakat tartalmazták, majd e témaspecifikus szúkített adatbázis szógyakorisági táblázatát vizsgáltam meg. Ebből feltárultak azok a további szavak, amelyek az adott témákat tartalmazó posztokban különösen gyakran jelentek meg (1. feltétel). Mielőtt azonban új elemet adtam volna a szótárhoz, a kiválasztott szót tartalmazó posztok egy kisebb mintáját $(\mathrm{N}=50)$ is átfutottam a teljes adatbázisból, hogy kiderüljön, hogy a szótárhoz adni kívánt elemet milyen kontextusban használják a Facebookon. Ez azért volt fontos, mert néhány esetben e vizsgálat arra világított rá, hogy bár az adott szó valóban gyakran jelenik meg a kiválasztott témában, de más témák kapcsán is visszatérően használják, így a szótárhoz adásával más témákat is ide rögzítene a módszer (2. feltétel). Egyes esetekben ez az ellenőrzés azt mutatta meg, hogy az adott szó más, nem a témához kapcsolódó szónak a része, ezért a szótárhoz csak úgy adhatjuk hozzá, ha kivételt is rögzítünk (például: az iskolát jelölő „iskol” szó része a „miskolc” szónak is). A kibővített szótár alapján aztán újra létrehoztam a témára fókuszáló szűkebb adatbázist és annak szógyakorisági tábláját, és e folyamatot egészen addig ismételtem, amíg a szótárakat már nem lehetett értelmes módon bővíteni. A szótárak véglegesítése után ezek alkalmassá váltak a Facebook-posztokban megjelenő témák azonosítására. Azokat a posztokat tekinthetjük egy adott témával foglalkozónak, amelyekben a szótár bármelyik eleme megjelenik. Fontos megjegyez-

\footnotetext{
${ }^{8}$ A kézi kódoláshoz a kódutasítás a következő volt: bármilyen utalás a poszt szövegében (korrupció) a közpénzek illegális vagy etikailag kifogásolható elköltésére; (migráció) illegális vagy legális migrációra, annak okaira vagy következményeire; (egészségügy) egészségügyi rendszerre, illetve az ahhoz kapcsolódó kihívásokra; (oktatás) az oktatási rendszerre, illetve az ahhoz kapcsolódó kihívásokra; (feljesztéspolitika) bármilyen fejlesztésre, beleértve a fejlesztési ígéreteket, illetve az átadási/felavatási eseményeket; (kampány) a kampányra, a választásokra vagy a politikai versengésre; (mobilizáció) bármilyen offline cselekvésre való felhívásra.
} 


\section{TEMATIKUS TANULMÁNYOK - Digitális szociológia}

ni, hogy ez a módszer csak az adott téma jelenlétét vagy hiányát rögzíti, azt már nem mutatja meg, hogy az mennyire játszik fontos szerepet a poszt egészében. Ez azt is jelenti, hogy egy poszt egynél több témával is foglalkozhat.

1. táblázat. A szövegbányászati módszerek teljesítményének ellenőrzése (az aranystandarddal való összehasonlítás alapján)

( $\mathrm{N}=1600$ a szótár-alapú és $\mathrm{N}=400$ a felügyelt gépi tanulás alapú módszereknél)

\begin{tabular}{|l|c|c|c|c|c|c|l|}
\hline & \multirow{2}{*}{$\begin{array}{c}\text { Pon- } \\
\text { tosság }\end{array}$} & $\begin{array}{c}\text { Fel- } \\
\text { idézés }\end{array}$ & $\mathrm{F} 1$ & teljes & $\begin{array}{c}\text { kormány- } \\
\text { párti } \\
\text { jelöltek }\end{array}$ & $\begin{array}{c}\text { ellenzéki } \\
\text { jelöltek }\end{array}$ & \multirow{2}{*}{ Módszer } \\
\hline Korrupció & $84 \%$ & $72 \%$ & 0.78 & $4.8 \%$ & $0.1 \%$ & $6.7 \%$ & Szótár-alapú \\
\hline Migráció & $77 \%$ & $100 \%$ & 0.87 & $5.4 \%$ & $9.6 \%$ & $3.7 \%$ & Szótár-alapú \\
\hline Egészségügy & $76 \%$ & $92 \%$ & 0.83 & $4.5 \%$ & $3.1 \%$ & $5.1 \%$ & Szótár-alapú \\
\hline Oktatás & $80 \%$ & $92 \%$ & 0.86 & $4.4 \%$ & $4.8 \%$ & $4.3 \%$ & Szótár-alapú \\
\hline Fejlesztéspol. & $86 \%$ & $80 \%$ & 0.83 & $5.4 \%$ & $12.1 \%$ & $2.7 \%$ & Szótár-alapú \\
\hline Kampány & $82 \%$ & $72 \%$ & 0.77 & $39.9 \%$ & $30.3 \%$ & $43.8 \%$ & $\begin{array}{l}\text { Felügyelt gépi tanulás } \\
\text { (AOC = 0.86; } \\
\text { alpha = 0.1) }\end{array}$ \\
\hline Mobilizáció & $81 \%$ & $67 \%$ & 0.73 & $10.3 \%$ & $9.3 \%$ & $10.6 \%$ & $\begin{array}{l}\text { Felügyelt gépi tanulás } \\
\text { (AOC = 0.81; } \\
\text { alpha = 0.6) }\end{array}$ \\
\hline $\begin{array}{l}\text { Negativitás } \\
\text { (kontrollváltozó) }\end{array}$ & $71 \%$ & $58 \%$ & 0.64 & $21 \%$ & 10.9 & $25.2 \%$ & $\begin{array}{l}\text { Felügyelt gépi tanulás } \\
\text { (AOC = 0.93; } \\
\text { alpha = 0.2) }\end{array}$ \\
\hline
\end{tabular}

Forrás: Saját szerkesztés

A kézileg kódolt aranystandarddal való összevetés azt mutatja, hogy a témaspecifikus szótárak meglehetősen jól funkcionáltak. A pontosság-értékek 76\% és 86\% között, míg a felidézés-értékek $72 \%$ és 100\% között vannak. A legalacsonyabb F1-érték így 0,78 (korrupció), ami még mindig magas szintű érvényességet jelent (1. táblázat). Az eredmények ugyanakkor azt is mutatják, hogy a korrupció témája szinte láthatatlan volt a kormánypárti képviselőjelöltek kommunikációjában, ezért e változó esetében nincs értelme a H3 hipotézis által felvázolt interakciós hatást vizsgálni - a korrupciós posztok ugyanis szinte kizárólag az ellenzékhez tartoznak.

A kampány és a mobilizáció témákat már jóval nehezebb specifikus szavakhoz kapcsolni, ezért ezek jelenlétét felügyelt gépi tanulási módszerekkel azonosítottam. Ennek érdekében az adatbázist a tf-idf súlyozás ${ }^{9}$ segítségével úgynevezett doku-

${ }^{9} \mathrm{~A}$ tf-idf egy olyan súlyozási technika melyben magasabb érték tartozik a gyakrabban használt kifejezésekhez, de a növekedés nem egyenesen arányos, mert minél gyakrabban fordul elő az adott kifejezés, annál kisebb az egy egységnyi előforduláshoz tartozó növekedés (Kwarler 2017: 100). 


\section{TEMATIKUS TANULMÁNYOK - Digitális szociológia}

mentum-kifejezés mátrixá alakítottam, amelyben a sorokban az egyes posztok, az oszlopokban pedig a posztokban megjelenő kifejezések jelennek meg. A felügyelt gépi tanuláshoz a logisztikus ElasticNet regressziós modellt alkalmaztam ${ }^{10}$ (Kwartler 2017), és a modelleket ahhoz az alpha paraméterhez optimalizáltam, amelyek a legjobb eredményt mutatták az aranystandardhoz $(\mathrm{N}=400)$ való illeszkedés tekintetében. A modellek teljesítményének értékelésekor az látható, hogy a felügyelt gépi tanulási módszer magas pontosságú eredményeket adott ki $(82 \%$ a kampány és $81 \%$ a mobilizáció esetében), míg a felidézés terén valamivel gyengébben, de még mindig elfogadható szinten teljesített (1. táblázat).

Tehát a szövegbányászati módszerek a szöveges adatokon jól működtek, azonban a módszer legnagyobb korlátja, hogy a posztokat pusztán a szöveges tartalom alapján kategorizálja, miközben a közösségi média-kommunikációban fontos szerepet játszanak a nem szöveges tartalmak is. A vizuális elemek figyelmen kívül hagyásából következő torzítás mértékének becslése érdekében a kézzel kódolt minta egy kisebb része $(\mathrm{N}=186)$ oly módon is rögzítve lett, hogy a kódoló a poszt egészét, így a poszthoz tartozó vizuális elemeket is figyelembe vette. A csak a szövegre fókuszáló és a poszt egészét vizsgáló kódolás összevetéséből az derült ki, hogy a szövegen túli elemek figyelembevétele a témák kategorizálásában nem eredményezett jelentős eltéréseket. A migráció, az egészségügy és az oktatás esetében nem volt olyan poszt, aminek kódolása különbözött volna a két adatbázisban, míg a korrupció és a fejlesztéspolitikánál csak egy poszt kapott eltérő kódot (1\%-os torzítás). Erősebb torzítás volt megfigyelhető a mobilizáció (3\%) és a kampány-téma (6\%) esetében, de ezek a szintek is elfogadhatóak. Következésképpen, a szövegalapú kategorizálás magas érvényességű eredményt kínál, hiszen az egyéb kommunikációs eszközök figyelembevétele nem javította jelentősen az adatok érvényességét.

Az érvényes eredmények eléréséhez számos, a felhasználói reaktivitásra potenciálisan hatást gyakorló egyéb változó kontroll alatt tartására is szükség van. A jelöltek szintjén a nem ( 1 = nő, összes poszt 15\%-a), politikai hovatartozás (1 = kormánypárti jelölt, 29\%), helyi politikai pozíció (1 = helyi polgármester vagy képviselőtestületi tag, 36\%), inkumbencia ( 1 = parlamenti képviselő, 36\%), és a jelöltség helye (1 = csak pártlista, 9\%) lett kontroll alatt tartva. Az oldal szintjén a követők száma (kampány végén, 21 és 608119 között, átlag = 16 064, szórás = 58 199), és a kampány alatt közzétett posztok száma került be a modellekbe. A posztok szintjén a közzététel időpontja (ahol 1 a kampány első napja, 51 az utolsó nap), és a poszt strukturális elemei, miszerint a poszt tartalmaz-e képet (1=igen, 52\%), videót (1=igen, 21\%), külső oldalról megosztott linket (1=igen, 22\%) vagy esemény-megosztást (1=igen, 2\%), valamint a szöveg hossza (karakterben, 1 és 18291 között, á = 304, sz = 488), lettek figyelembe véve. A posztok tartalmával kapcsolatban azonban a legrobosztu-

${ }^{10}$ Az elemzéshez az R-alapú glmnet (Friedman et al. 2010), a caret (Kuhn 2008) és a pROC (Robin et al. 2011) csomagokat használtam. 


\section{TEMATIKUS TANULMÁNYOK - Digitális szociológia}

sabb eredmény a szakirodalomban az, hogy a negatív tartalmak több felhasználói reakciót váltanak ki (lásd: Bene 2020, Heiss et al. 2019, Xenos et al. 2017). A fentebb ismertetett felügyelt gépi tanulási módszerrel tettünk kísérletet a negatív tónusú posztok azonosítására. Ebben az esetben a módszer gyengébb érvényességgel működött, mint a témák esetében, különösen a felidézés terén teljesített gyengén (lásd, 1. táblázat): tehát míg a legtöbb negatívként azonosított poszt valóban negatív, a valóban negatív tartalmak egy nem elhanyagolható hányadát nem ismerte fel a modell. Azonban figyelembe véve e faktor elméleti fontosságát, az eredmények robosztusságát növelendő, egy külön modellben az ily módon azonosított negativitás hatását is kontroll alatt tartom. Ráadásul, más kutatásokban ehhez hasonló érvényességi szinten mért érzelmi változókat független változóként is felhasználnak (Eberl et al. 2020).

Mivel az adathalmaz többszintű struktúrába rendeződik, és a függő változók túlszórt count-jellegű változók, ezért többszintű negatív binomiális regressziómodellekel teszteltem a hipotéziseket, ahol az oldalak szintjén random intercept-et alkalmaztam. ${ }^{11}$ Négy modell tartozik minden interaktivitás-típushoz: az első az interakciós együtthatók nélkül, csak a független változókat tartalmazza. Az interakciós hatások a második modellben jelennek meg. Mivel a mobilizáció változó fogalmilag a kampány-változó altípusa, ezért ennek hatását külön modellben teszteltem, tehát míg az első két modellben a kampány változó szerepel, és a mobilizáció változó nem, a harmadik modellbe a mobilizáció változó kerül be, és a kampány változó pedig ki. Végezetül a negativitás hatását, a változóval kapcsolatos érvényességi fenntartások miatt, külön modellben kontrollálom, így az csak a negyedik modellben jelenik meg.

\section{Eredmények}

A modellek eredményei a 2., 3. és 4. táblázatokban láthatóak. A hipotézisek tekintetében az eredmények meglehetősen vegyesek. A legegyértelmübb eredmény a korrupció témájához kapcsolódik: a korrupcióval foglalkozó posztok mindegyik dimenzióban több interakciót eredményeznek. A másik fő kampánytéma, a migráció kapcsán azonban már összetettebb a kép. Az interakciós együtthatók nélküli modellekben az látható, hogy a migrációval foglalkozó posztok kevesebb Reakciót és kommentet kapnak, viszont szignifikánsan gyakrabban osztják meg őket. Ebből tehát úgy tűnik, hogy míg a korrupció egy interakció-növelő téma, a migráció inkább viszszatartó erejű e tekintetben. Az interakciós együtthatók azonban árnyalják a képet. A párthovatartozás és a migráció témája mindegyik interakció-típusnál negatív kapcsolatot mutat, ami éppen ellentétes azzal, amit a témagazda-hatás értelmében vártunk. Meglepő módon ugyanis az ellenzéki politikusok oldalain megjelenő migrációs

${ }^{11}$ Az elemzéshez az R-alapú glmmADMB (Fournier et al. 2012) csomagot használtam. 


\section{TEMATIKUS TANULMÁNYOK - Digitális szociológia}

posztok több reakciót, kommentet és megosztást váltottak ki más posztokhoz képest, miközben a kormánypárti politikusok migrációs posztjaira a felhasználók éppen hogy még jóval kevésbé is reagáltak, kommentelték vagy osztották meg őket más tartalmakkal összehasonlítva (1.ábra). Tehát a migráció témája kapcsán egyfajta fordított témagazda-hatás rajzolódik ki: a témagazdák követői kevésbé reagálnak erre a tartalomtípusra, míg a nem témagazdák éppenhogy sikeresebbek riválisuk saját témájában.

A közpolitikai témák kapcsán is vegyes eredményeket látunk. A H2-t az oktatáspolitika esetében teljes mértékig, míg az egészségügynél csak részben fogadhatjuk el. Az oktatással foglalkozó posztok szignifikánsan kevesebb Reakciót, kommentet és megosztást kaptak, míg az egészségüggyel kapcsolatos tartalmakat kevésbé kommentelik, ugyanakkor a megosztások terén népszerủek, míg a Reakcióknál nincs szignifikáns kapcsolat. Ezzel szemben a fejlesztéspolitika témája más mintázatot mutat. A fejlesztéspolitikával kapcsolatos posztok szignifikánsan több kommentet és megosztást kapnak, a Reakciók esetében pedig nem figyelhető meg együttjárás. Az interakciós együtthatók azonban itt is árnyalják az eredményeket. A témagazda-hatás egyedül az oktatás kapcsán érvényesül, és itt is csak a kommentek és a reakciók esetében. Míg az oktatással kapcsolatos posztok mindkét politikai táborban népszerütlenek, a kormánypárti képviselők oldalain még kevesebb figyelmet kapnak, mint az ellenzéki politikusoknál. A megosztások esetében viszont ismét a fordított témagazda-hatás rajzolódik ki: miközben mindkét táborban kevesebb megosztást kapnak az oktatással kapcsolatos posztok, ez a tendencia erösebb az ellenzéki politikusoknál, tehát az ellenzéki politikusok oktatással kapcsolatos bejegyzéseit még kevésbé osztják meg, mint a kormánypárti jelöltek esetében (1. ábra). Az egészségügy és a fejlesztéspolitika témáját szintén jelentős részben a fordított témagazda-hatás jellemzi. A kormánypárti politikusok követői nagyobb arányban reagálnak, kommentelnek és osztanak meg egészségüggyel kapcsolatos tartalmakat, bár a kommentelés esetében a kapcsolat nem szignifikáns. Mindeközben, az ellenzéki követök a feljesztéspolitikával kapcsolatos tartalmakat reagálják és kommentelik magasabb arányban, mint a kormánypártiak.

A kampány és mobilizáció témákhoz kapcsolódó eredményeket jóval könnyebb értelmezni. A kampánytémák minden dimenzióban több interakciót váltanak ki, míg a mobilizációra törekvő posztokat szignifikánsan kevesebben reagálják, kommentelik és osztják tovább. Ezek az eredmények azt jelzik, hogy az emberek valóban erősen érdeklődnek a kampány iránt, és a kampányperiódusban különösen nyitottak a választásokkal kapcsolatos tartalmakra, de nem kívánnak az választási versengés aktív résztvevőivé válni. Ezért mind a H4, mind a H4a erős megerősítést nyert. A negativitás beléptetése a modellekbe nem változtatta meg a hatások szignifikanciáját, irányát és nagyságát. 


\section{TEMATIKUS TANULMÁNYOK - Digitális szociológia}

2. táblázat. A jelöltek posztjaira való Reakciók számát magyarázó random-intercept negatív binomiális regressziómodellek együtthatói

\begin{tabular}{|c|c|c|c|c|}
\hline & 1. modell & 2. modell & 3. modell & 4. modell \\
\hline migráció & $-0.22(.02)^{* * *}$ & $0.02(.03)$ & $0.02(.03)$ & $0.03(.03)$ \\
\hline korrupció & $\mathbf{0 . 1 1}(.02)^{* * *}$ & $\mathbf{0 . 1 0}(.02)^{* * *}$ & $\mathbf{0 . 1 1}(.02)^{* * *}$ & $\mathbf{0 . 1 0}(.02)^{* * *}$ \\
\hline egészségügy & $-0.01(.02)$ & $\mathbf{- 0 . 0 9}(.03)^{* *}$ & $\mathbf{- 0 . 0 9}(.03)^{* * *}$ & $-0.09(.03)^{* *}$ \\
\hline oktatás & $-\mathbf{0 . 0 7}(.02)^{* *}$ & $-0.02(.03)$ & $-0.03(.03)$ & $-0.02(.03)$ \\
\hline fejlesztéspolitika & $0.00(.02)$ & $0.07(.03)^{*}$ & $0.03(.03)$ & $0.07(.03)^{*}$ \\
\hline kampány & $\mathbf{0 . 0 8}(.01)^{* * *}$ & $0.09(.01)^{* * *}$ & & $\mathbf{0 . 0 9}(.01)^{* * *}$ \\
\hline mobilizáció & & & $\mathbf{- 0 . 1 1}(.02)^{* * *}$ & \\
\hline párt*migráció & & $-0.52(.04)^{* * *}$ & $-0.49(.04)^{* * *}$ & $-\mathbf{0 . 5 2}(.04)^{* * *}$ \\
\hline párt *egészségügy & & $0.18(.05)^{* * *}$ & $0.18(.05)^{* * *}$ & $0.18(.05)^{* * *}$ \\
\hline párt *oktatás & & $-0.16(.05)^{* * *}$ & $\mathbf{- 0 . 1 8}(.05)^{* * *}$ & $\mathbf{- 0 . 1 6}(.05)^{* * *}$ \\
\hline párt*fejlesztéspolitika & & $-0.09(.04)^{*}$ & $-0.08(.04)^{\#}$ & $-0.09(.04)^{*}$ \\
\hline szöveghossz & $\mathbf{0 . 0 0}(.00)^{* * *}$ & $\mathbf{0 . 0 0}(.00)^{* * *}$ & $\mathbf{0 . 0 0}(.00)^{* * *}$ & $\mathbf{0 . 0 0}(.00)^{* * *}$ \\
\hline kép & $\mathbf{0 . 2 0}(.03)^{* * *}$ & $0.20(.03)^{* * *}$ & $\mathbf{0 . 2 0}(.03)^{* * *}$ & $0.20(.03)^{* * *}$ \\
\hline videó & $-0.13(.03)^{* * *}$ & $-0.13(.03)^{* * *}$ & $\mathbf{- 0 . 1 3}(.03)^{* * *}$ & $\mathbf{- 0 . 1 3}(.03)^{* * *}$ \\
\hline link & $-0.20(.03)^{* * *}$ & $-0.20(.03)^{* * *}$ & $\mathbf{- 0 . 2 1}(.03)^{* * *}$ & $\mathbf{- 0 . 2 0}(.03)^{* * *}$ \\
\hline esemény & $-1.72(.05)^{* * *}$ & $-1.71(.05)^{* * *}$ & $\mathbf{- 1 . 7 4}(.05)^{* * *}$ & $\mathbf{- 1 . 7 2}(.05)^{* * *}$ \\
\hline nap & $0.01(.00)^{* * *}$ & $0.01(.00)^{* * *}$ & $\mathbf{0 . 0 1}(.00)^{* * *}$ & $\mathbf{0 . 0 1}(.00)^{* * *}$ \\
\hline posztok száma & $\mathbf{0 . 0 0}(.00)^{* * *}$ & $\mathbf{0 . 0 0}(.00)^{* * *}$ & $\mathbf{0 . 0 0}(.00)^{* * *}$ & $\mathbf{0 . 0 0}(.00)^{* * *}$ \\
\hline követők száma & $\mathbf{0 . 0 0}(.00)^{* * *}$ & $\mathbf{0 . 0 0}(.00)^{* * *}$ & $\mathbf{0 . 0 0}(.00)^{* * *}$ & $\mathbf{0 . 0 0}(.00)^{* * *}$ \\
\hline nem & $-0.10(.14)$ & $-0.10(.14)$ & $-0.10(.14)$ & $-0.10(.14)$ \\
\hline párt & $0.63(.15)^{* * *}$ & $0.67(.15)^{* * *}$ & $0.65(.15)^{* * *}$ & $0.66(.15)^{* * *}$ \\
\hline helyi pozíció & $0.28(.11)^{*}$ & $0.28(.11)^{*}$ & $0.28(.11)^{*}$ & $0.28(.11)^{*}$ \\
\hline inkumbens & $0.65(.14)^{* * *}$ & $0.65(.14)^{* * *}$ & $0.65(.14)^{* * *}$ & $0.65(.14)^{* * *}$ \\
\hline csak listás jelölt & $0.05(.17)$ & $0.05(.17)$ & $0.06(.17)$ & $0.05(.11)$ \\
\hline negativitás & & & & $-0.02(.01)^{\#}$ \\
\hline konstans & $2.47(.10)^{* * *}$ & $2.46(.10)^{* * *}$ & $2.49(.10)$ & $2.46(.10)$ \\
\hline $\begin{array}{l}\text { random intercept vari- } \\
\text { anciája }\end{array}$ & $1.176(1.085)$ & $1.173(1.083)$ & $1.174(1.084)$ & $1.174(1.083)$ \\
\hline Log-likelihood & -184781 & -184683 & -184702 & -184682 \\
\hline diszperzió-paraméter & $1.49(.01)$ & $1.50(0.1)$ & $1.50(.01)$ & $1.50(.01)$ \\
\hline AIC & 369606 & 369418 & 369456 & 369418 \\
\hline $\mathrm{N}$ (1. szint) & 37284 & 37284 & 37284 & 37284 \\
\hline $\mathrm{N}$ (2. szint) & 507 & 507 & 507 & 507 \\
\hline
\end{tabular}

Megjegyzés: Zárójelben a standard hiba. ${ }^{\#} \mathrm{p}<.10 ;{ }^{*} \mathrm{p}<.05 ;{ }^{* *} \mathrm{p}<.01 ;{ }^{* * *} \mathrm{p}<.001$

Forrás: Saját szerkesztés 
www. metszetek.unideb.hu

\section{TEMATIKUS TANULMÁNYOK - Digitális szociológia}

3. táblázat. A jelöltek posztjaira való kommentek számát magyarázó random-intercept negatív binomiális regressziómodellek együtthatói

\begin{tabular}{|c|c|c|c|c|}
\hline & 1. modell & 2. modell & 3. modell & 4. modell \\
\hline migráció & $-0.06(.03)^{\#}$ & $0.09(.05)^{\#}$ & $\mathbf{0 . 1 0}(.05)^{*}$ & $0.07(.05)$ \\
\hline korrupció & $0.12(.04)^{* *}$ & $0.10(.04)^{* *}$ & $0.11(.04)^{* *}$ & $0.07(.04)^{*}$ \\
\hline egészségügy & $-0.09(.04)^{*}$ & $\mathbf{- 0 . 1 6}(.04)^{* * *}$ & $-\mathbf{0 . 1 7}(.04)^{* * *}$ & $-0.16(.04)^{* * *}$ \\
\hline oktatás & $-0.30(.04)^{* * *}$ & $-\mathbf{0 . 1 9}(05)^{* * *}$ & $-\mathbf{0 . 1 9}(05)^{* * *}$ & $-\mathbf{0 . 1 8}(05)^{* * *}$ \\
\hline fejlesztéspolitika & $0.08(.04)^{*}$ & $0.25(.06)^{* * *}$ & $0.18(.06)^{* *}$ & $0.25(.06)^{* * *}$ \\
\hline kampány & $0.19(.02)^{* * *}$ & $0.19(.02)^{* * *}$ & & $\mathbf{0 . 2 0}(.02)^{* * * *}$ \\
\hline mobilizáció & & & $\mathbf{- 0 . 1 2}(.03)^{* * *}$ & \\
\hline párt*migráció & & $\mathbf{- 0 . 3 4}(.07)^{* * *}$ & $\mathbf{- 0 . 2 8}(.07)^{* * *}$ & $-0.34(.07)^{* * *}$ \\
\hline párt *egészségügy & & $0.12(.09)$ & $0.11(.09)$ & $0.12(.09)$ \\
\hline párt *oktatás & & $-0.41(.08)^{* * *}$ & $\mathbf{- 0 . 4 5}(.08)^{* * *}$ & $-0.41(.08)^{* * *}$ \\
\hline párt*fejlesztéspolitika & & $-0.28(.07)^{* * *}$ & $-0.26(.07)^{* * *}$ & $-0.26(.07)^{* * *}$ \\
\hline Szöveghossz & $\mathbf{0 . 0 0}(.00)^{* * *}$ & $\mathbf{0 . 0 0}(.00)^{* * *}$ & $\mathbf{0 . 0 0}(.00)^{* * *}$ & $\mathbf{0 . 0 0}(.00)^{* * *}$ \\
\hline kép & $-0.16(.05)^{* * *}$ & $-0.16(.05)^{* * *}$ & $-0.16(.05)^{* * *}$ & $-\mathbf{0 . 1 5}(.05)^{* * *}$ \\
\hline videó & $-0.24(.05)^{* * *}$ & $-0.25(.05)^{* * *}$ & $\mathbf{- 0 . 2 5}(.05)^{* * *}$ & $-0.25(.05)^{* * *}$ \\
\hline link & $-0.21(.05)^{* * *}$ & $-0.21(.05)^{* * *}$ & $-0.23(.05)^{* * *}$ & $-0.23(.05)^{* * *}$ \\
\hline esemény & $-2.64(.10)^{* * *}$ & $-2.64(.10)^{* * *}$ & $-2.66(.10)^{* * *}$ & $-2.62(.10)^{* * *}$ \\
\hline nap & $\mathbf{0 . 0 1}(.00)^{* * *}$ & $\mathbf{0 . 0 1}(.00)^{* * *}$ & $\mathbf{0 . 0 1}(.00)^{* * *}$ & $\mathbf{0 . 0 1}(.00)^{* * *}$ \\
\hline posztok száma & $\mathbf{0 . 0 0}(.00)^{* * *}$ & $\mathbf{0 . 0 0}(.00)^{* * *}$ & $\mathbf{0 . 0 0}(.00)^{* * *}$ & $\mathbf{0 . 0 0}(.00)^{* * *}$ \\
\hline követők száma & $\mathbf{0 . 0 0}(.00)^{* * *}$ & $\mathbf{0 . 0 0}(.00)^{* * *}$ & $\mathbf{0 . 0 0}(.00)^{* * *}$ & $\mathbf{0 . 0 0}(.00)^{* * *}$ \\
\hline nem & $-0.16(.14)$ & $-0.15(.14)$ & $-0.15(.14)$ & $-0.15(.14)$ \\
\hline párt & $-0.19(.15)$ & $-0.15(.15)$ & $-0.17(.15)$ & $-0.13(.15)$ \\
\hline helyi pozíció & $0.37(.11)^{* * *}$ & $0.38(.11)^{* * *}$ & $0.38(.11)^{* * *}$ & $0.37(.11)^{* * *}$ \\
\hline inkumbens & $0.61(.14)^{* * *}$ & $0.61(.14)^{* * *}$ & $0.61(.14)^{* * *}$ & $0.61(.14)^{* * *}$ \\
\hline csak listás jelölt & $0.18(.17)$ & $0.18(.17)$ & $0.18(.17)$ & $0.17(.17)$ \\
\hline negativitás & & & & $\mathbf{0 . 1 5}(.02)^{* * *}$ \\
\hline konstans & $0.18(.11)^{\#}$ & $0.17(.11)^{\#}$ & $0.25(.11)^{*}$ & $0.15(.11)$ \\
\hline random intercept varianciája & $1.157(1.076)$ & $1.155(1.075)$ & $1.157(1.076)$ & $1.149(1.072)$ \\
\hline Log-likelihood & -92840.5 & -92805.7 & -92866.4 & -92776.1 \\
\hline diszperzió-paraméter & $0.61(.01)$ & $0.61(.01)$ & $0.61(.01)$ & $0.61(.01)$ \\
\hline AIC & 185725 & 185663.4 & 185784.8 & 185606.2 \\
\hline $\mathrm{N}$ (1. szint) & 37554 & 37554 & 37554 & 37554 \\
\hline$N$ (2. szint) & 507 & 507 & 507 & 507 \\
\hline
\end{tabular}

Megjegyzés: Zárójelben a standard hiba. ${ }^{\#} \mathrm{p}<.10 ;{ }^{*} \mathrm{p}<.05 ;{ }^{* *} \mathrm{p}<.01 ;{ }^{* * *} \mathrm{p}<.001$

Forrás: Saját szerkesztés 
www. metszetek.unideb.hu

\section{TEMATIKUS TANULMÁNYOK - Digitális szociológia}

4. táblázat. A jelöltek posztjaira való megosztások számát magyarázó random-intercept negatív binomiális regressziómodellek együtthatói

\begin{tabular}{|c|c|c|c|c|}
\hline & 1. modell & 2. modell & 3. modell & 4. modell \\
\hline migráció & $\mathbf{0 . 0 5}(.03)^{*}$ & $0.42(.04)^{* * *}$ & $0.42(.04)^{* * *}$ & $\mathbf{0 . 3 9}(.04)^{* * *}$ \\
\hline korrupció & $0.22(03)^{* * *}$ & $0.21(.03)^{* * *}$ & $0.22(.03)^{* * *}$ & $\mathbf{0 . 1 9}(.03)^{* * *}$ \\
\hline egészségügy & $0.12(.03)^{* * *}$ & $0.06(.03)^{\#}$ & $0.05(.03)$ & $0.06(.03)^{\#}$ \\
\hline oktatás & $-0.15(.03)^{* * *}$ & $-0.23(.04)^{* * *}$ & $-0.23(.04)^{* * *}$ & $-0.23(.04)^{* * *}$ \\
\hline fejlesztéspolitika & $0.24(.03)^{* * *}$ & $0.17(.04)^{* * *}$ & $\mathbf{0 . 1 7}(.04)^{* *}$ & $0.16(.04)^{* * *}$ \\
\hline kampány & $0.11(.01)^{* * *}$ & $0.12(.01)^{* * *}$ & & $\mathbf{0 . 1 3}(.01)^{* * *}$ \\
\hline mobilizáció & & & $\mathbf{- 0 . 1 1}(.02)^{* * *}$ & \\
\hline párt*migráció & & $-0.85(.05)^{* * *}$ & $\mathbf{- 0 . 8 0}(.05)^{* * *}$ & $-0.85(.05)^{* * *}$ \\
\hline párt *egészségügy & & $0.21(.07)^{* *}$ & $0.20(.07)^{* *}$ & $0.21(.07)^{* *}$ \\
\hline párt *oktatás & & $0.17(.06)^{* *}$ & $0.15(.06)^{*}$ & $0.17(.06)^{* *}$ \\
\hline párt*fejlesztéspolitika & & $0.09(.06)$ & $0.10(.06)^{\#}$ & $0.09(.06)$ \\
\hline szöveghossz & $\mathbf{0 . 0 0}(.00)^{* * *}$ & $\mathbf{0 . 0 0}(.00)^{* * *}$ & $\mathbf{0 . 0 0}(.00)^{* * *}$ & $\mathbf{0 . 0 0}(.00)^{* * *}$ \\
\hline kép & $0.40(.04)^{* * *}$ & $0.42(.04)^{* * *}$ & $0.42(.04)^{* * *}$ & $\mathbf{0 . 4 2}(.04)^{* * *}$ \\
\hline videó & $\mathbf{0 . 5 1}(.04)^{* * *}$ & $0.53(.04)^{* * *}$ & $0.53(.04)^{* * *}$ & $\mathbf{0 . 5 2}(.04)^{* * *}$ \\
\hline link & $0.49(.04)^{* * *}$ & $0.50(.04)^{* * *}$ & $0.49(.04)^{* * *}$ & $0.48(.04)^{* * *}$ \\
\hline esemény & $-7.05(.39)^{* * *}$ & $-7.03(.39)^{* * *}$ & $-7.03(.39)^{* * *}$ & $-7.01(.39)^{* * *}$ \\
\hline nap & $\mathbf{0 . 0 0}(.00)^{* * *}$ & $\mathbf{0 . 0 0}(.00)^{* * *}$ & $0.01(.00)^{* * *}$ & $\mathbf{0 . 0 0}(.00)^{* * *}$ \\
\hline posztok száma & $\mathbf{0 . 0 1}(.00)^{* * *}$ & $0.01(.00)^{* * *}$ & $\mathbf{0 . 0 1}(.00)^{* * *}$ & $\mathbf{0 . 0 1}(.00)^{* * *}$ \\
\hline követők száma & $\mathbf{0 . 0 0}(.00)^{* * *}$ & $\mathbf{0 . 0 0}(.00)^{* * *}$ & $0.00(.00)^{* * *}$ & $\mathbf{0 . 0 0}(.00)^{* * *}$ \\
\hline nem & $-0.31(.14)^{*}$ & $-0.31(.14)^{*}$ & $-0.30(.14)^{*}$ & $-0.30(.14)^{*}$ \\
\hline párt & $0.05(.15)$ & $0.08(.15)$ & $0.06(.15)$ & $0.10(.15)$ \\
\hline helyi pozíció & $0.47(.11)^{* * *}$ & $0.47(.11)^{* * *}$ & $0.47(.11)^{* * *}$ & $0.47(.11)^{* * *}$ \\
\hline inkumbens & $0.71(.14)^{* * *}$ & $0.71(.14)^{* * *}$ & $0.70(.14)^{* * *}$ & $0.70(.14)^{* * *}$ \\
\hline csak listás jelölt & $0.02(.17)$ & $0.03(.17)$ & $0.04(.17)$ & $0.03(.17)$ \\
\hline negativitás & & & & $0.15(.02)^{* * *}$ \\
\hline konstans & $0.38(.10)^{* * *}$ & $0.35(.10)^{* * *}$ & $0.40(.10)^{* * *}$ & $0.33(.10)^{* *}$ \\
\hline $\begin{array}{l}\text { random intercept } \\
\text { varianciája }\end{array}$ & $1.206(1.098)$ & $1.200(1.095)$ & $1.197(1.094)$ & $1.191(1.092)$ \\
\hline Log-likelihood & -129929 & -129790 & -129820 & -129740 \\
\hline diszperzió-paraméter & $0.91(.01)$ & $0.92(.01)$ & $0.92(.01)$ & $0.92(.01)$ \\
\hline AIC & 259902 & 259632 & 259692 & 259534 \\
\hline $\mathrm{N}$ (1. szint) & 37486 & 37486 & 37486 & 37486 \\
\hline $\mathrm{N}$ (2. szint) & 507 & 507 & 507 & 507 \\
\hline
\end{tabular}

Megjegyzés: Zárójelben a standard hiba. ${ }^{\#} \mathrm{p}<.10 ;{ }^{*} \mathrm{p}<.05 ;{ }^{* *} \mathrm{p}<.01 ;{ }^{* * *} \mathrm{p}<.001$

Forrás: Saját szerkesztés 


\section{TEMATIKUS TANULMÁNYOK - Digitális sZociológia}
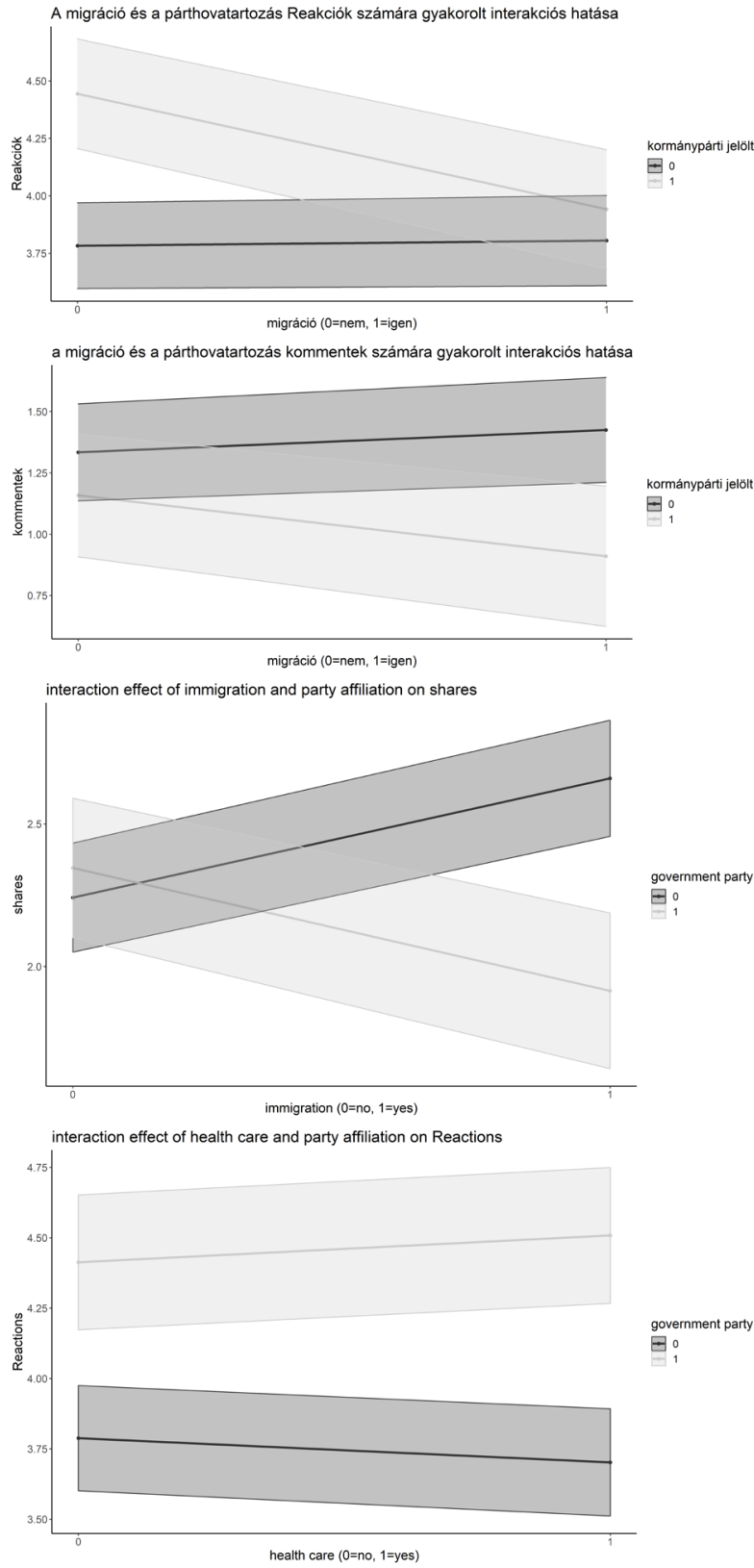


\section{TEMATIKUS TANULMÁNYOK - Digitális szociológia}
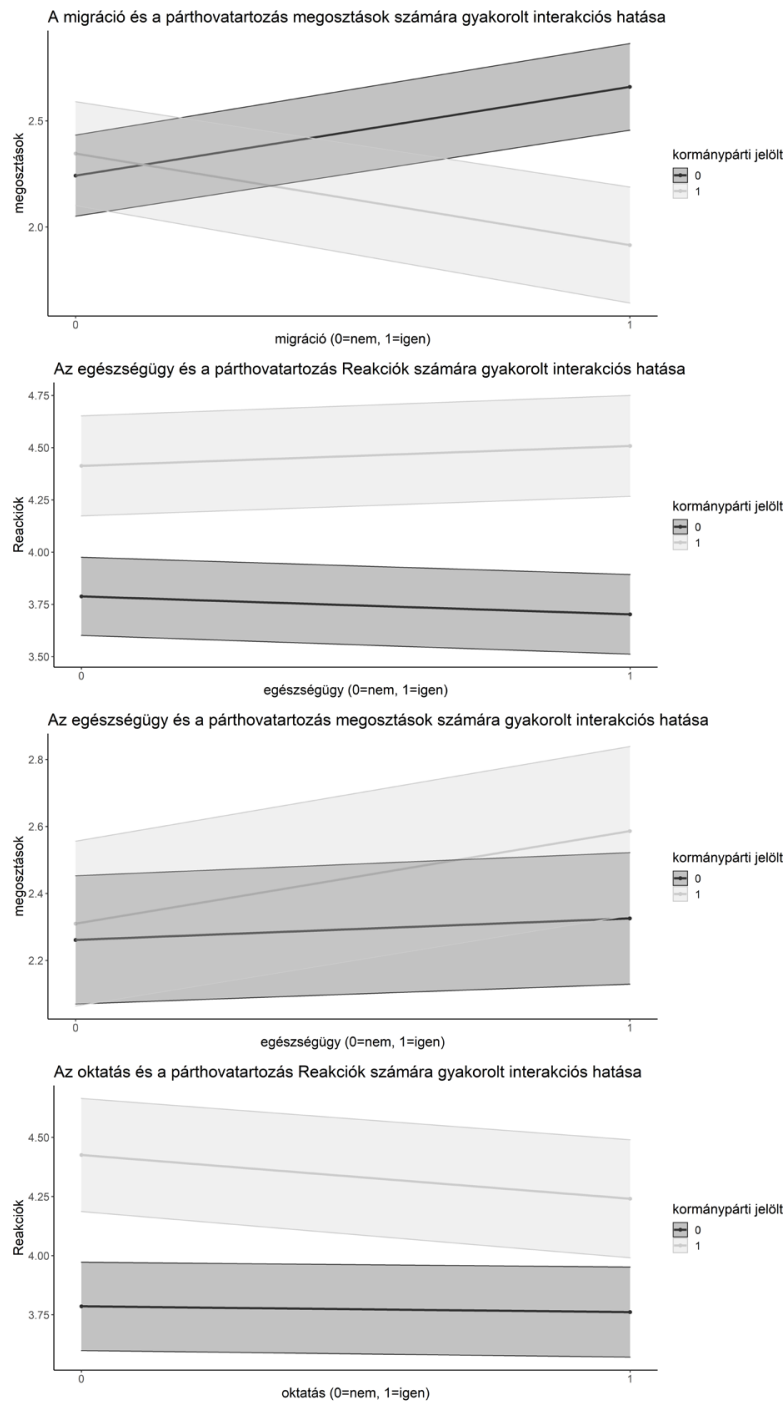
www. metszetek.unideb.hu

\section{TEMATIKUS TANULMÁNYOK - Digitális szociológia}
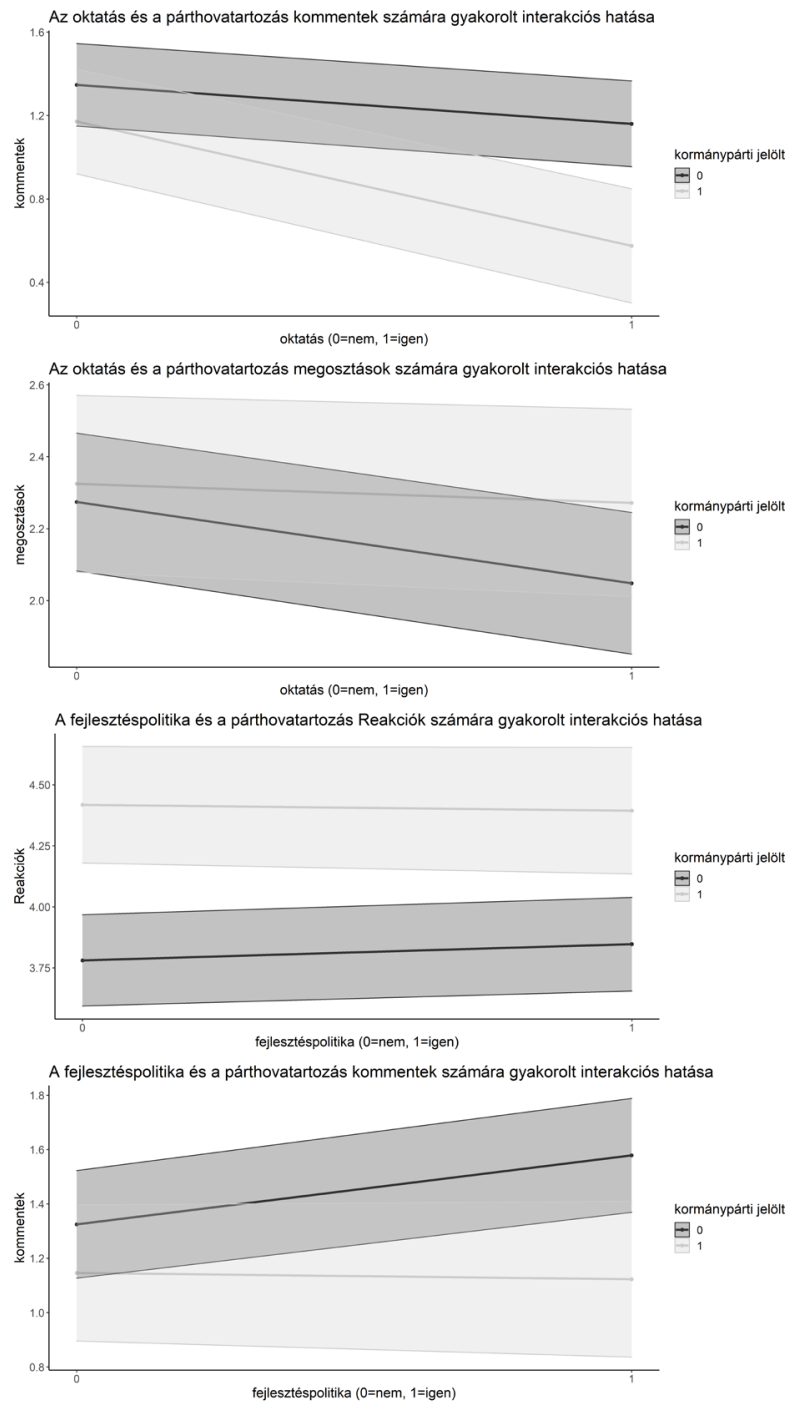

1. ábra. Szignifikáns interakciós hatások Forrás: Saját szerkesztés 


\section{TEMATIKUS TANULMÁNYOK - Digitális szociológia}

\section{Összegzés}

A politikai kommunikáció viralizációjának tézisére támaszkodva a tanulmány kiindulópontja az volt, hogy a politikai kommunikáció egyre inkább az állampolgári kommunikáció sajátosságaihoz igazodik, mivel az állampolgárok reakciói képesek a politikai szereplők üzeneteit széles választói rétegekhez eljuttatni a közösségi oldalakon. Napjaink politikai kommunikációjának megértéséhez ezért fontos feltárnunk az állampolgári reaktivitás működését. A tanulmány az egyre bővülő szakirodalom két lényeges hiányosságát kísérelte meg pótolni a 2018-as magyarországi országgyưlési választási kampány kontextusában végzett vizsgálattal. Először is, a kutatás elsődleges fókusza az egyébként eddig kevéssé vizsgált politikai témák kérdése: arra koncentrált, hogy a különböző politikai témák hogyan hatnak a felhasználói reakciókra a politikusok oldalain. Másodszor, automatizált tartalomelemzési eszközök alkalmazásával a hipotéziseket a korábbi kutatásokhoz képest jóval kiterjedtebb és átfogóbb adatbázison tesztelte, elkerülve ezáltal a mintavételi döntésekből fakadó általánosíthatósági korlátokat. A tanulmány bemutatta, hogy a szótár-alapú és a felügyelt gépi tanulásra támaszkodó szövegbányászati módszerek alkalmasak a Facebook posztokban felbukkanó főbb politikai témák magas megbízhatósági szinten való azonosítására.

A hipotézisek felállításához a kampány vezető témáit a kutatás három csoportra bontotta: kiemelt, közpolitikai és kampány témák lettek megkülönböztetve. Bár a hipotézisek ezekre a témacsoportokra vonatkoztak, az eredmények azt mutatják, hogy e témák a felhasználói aktivitásra való hatásuk tekintetében nem feltétlenül mozognak így együtt.

Az első hipotézis a korrupció kapcsán teljes megerősítésre talált, hiszen ez a téma több reakciót váltott ki minden dimenzióban, a migrációnál azonban árnyaltabb a kép. Ekkor meglepő módon csak az ellenzéki politikusok posztjainál igazolódott a feltevés, az ő migrációs tartalmaik valóban több reakciót váltanak ki. A kormánypárti politikusoknál azonban a migrációs tartalmak kevesebb felhasználói interakciót eredményeztek, mint más tartalmak, ami különösen meglepő annak fényében, hogy a kormánypártok 2018-as kampánya nagymértékben erről a témáról szólt. Összességében tehát azt mondhatjuk, hogy általános szabályként nem lehet kijelenteni, hogy a kiemelt kampánytémáknak reaktivitást erősítő hatása van.

Hasonlóan összetett a helyzet a második hipotézis esetében is. Az egészségügy, és még inkább az oktatáspolitika nem számít túl népszerű Facebook témáknak, azonban azt nem állíthatjuk, hogy a közpolitikai témák általánosságban népszerűtlenek, hiszen a fejlesztéspolitika képében találtunk olyan szakpolitikai ügyet, ami sikeres a felhasználói interakciók kiváltásában. Ismét tehát azt látjuk, hogy míg a hipotézis részben igaznak bizonyul, a közpolitikára vonatkozó általános állításként már nem állja meg a helyét.

Ezek az eredmények azt jelzik, hogy a politikai témák egyéni jellege is számít. Bár e különböző karakterjegyek hatása további vizsgálatokat igényel, néhány előzetes 


\section{TEMATIKUS TANULMÁNYOK - Digitális szociológia}

feltevést meg lehet fogalmazni. Először is, a témák különbözhetnek abban a tekintetben, hogy milyen érzelmi reakciók kapcsolódnak hozzájuk. A korrupció például egy általánosan helytelenített politikai magatartásforma, amelyhez leggyakrabban a düh érzése kapcsolódik, ami egy olyan érzés, amit viszonylag könnyű másokkal megosztani: az emberek gyakran beszélnek egymással azokról a dolgokról, ami feldühíti őket. Ezzel szemben a migráció érzelmileg már egy jóval diffúzabb ügy, melylyel kapcsolatban az emberek érzelmileg inkább megosztottak. A domináns negatív érzelem azonban itt talán a félelem lehet, mely érzést már jóval nehezebb a kiterjedt ismerősi hálózat előtt felvállalni, hiszen a félelem általában a gyengeség jeleként értelmeződik. Másodszor, a felhasználói aktivitás szintjére hatással lehet az adott téma földrajzi közelsége is. A fejlesztéspolitika sikere talán abban rejlik, hogy az ezzel kapcsolatos posztok gyakran helyi fejlesztésekkel kapcsolatos helyi szinten releváns információk, amelyeket könnyen meg lehet osztani és vitatni a környékbeli ismerősökkel. Ezzel szemben az egészségügy és az oktatáspolitika esetében az jelenthet nehézséget, hogy a politikai szereplők e témákat sok esetben rendszerszinten tárgyalják. Későbbi tanulmányoknak érdemes tesztelni ezeket a feltevéseket.

Az eredmények csak a kampány- és mobilizáció témával kapcsolatos hipotéziseket támasztották teljes mértékben alá. Kampányidőszakban a követők előszeretettel interaktálnak kampánytartalmakkal még úgy is, hogy ezekből óriási a kínálat. A politikai versengés ezért egy olyan témának tűnik, amihez könnyen kapcsolódnak a választók. Ugyanakkor aktív résztvevővé nem akarnak válni, hiszen a választókat offline aktivitásokra felhívó tartalmakat nem szívesen promotálnak reakcióikkal, kommentjeikkel és megosztásaikkal.

A legváratlanabb és éppen ezért legizgalmasabb eredmény azonban a témagazda elmélethez kapcsolódik. Az ebből az elméletből levezetett hipotézis csak elvétve teljesül: egyedül az oktatáspolitika témája az, ahol a témagazda politikai oldal politikusai valamivel több interakciót képesek kiváltani, mint a másik oldal ugyanebben a témában közzétett posztjai. A korrupcióhoz kapcsolódó eredmény is valamelyest ide sorolható még, hiszen az ide tartozó posztokat szinte csak a témagazda ellenzéki politikusok tették közzé, így a szignifikáns hatások azt mutatják, hogy jól teljesítettek saját témájukban - itt azonban a kormányoldal teljesítményével nincs mód az eredmények összevetésére a vonatkozó posztok hiányában. Ezentúl azonban a legtöbb esetben éppen fordított témagazdag hatás azonosítható, azaz a témagazdák saját témájukban még gyengébb interaktivitás-kiváltó potenciállal is rendelkeznek, mint a másik oldal ugyanabban a témában. Ráadásul ez a fordított hatás a politikai spektrum mindkét oldalán megfigyelhető: a kormánypárti jelöltek egészségüggyel kapcsolatos posztjai sikeresebbek, míg az ellenzék a migráció és a fejlesztéspolitika terén ért el jobb eredményeket.

Empirikus bizonyítékok hiányában e megfigyelések okairól csak spekulálni lehet. A magyar kontextusban elég jól dokumentálták, hogy a politikai táborok által birtokolt témák valóban jelentős hatást voltak képesek gyakorolni saját szavazóik 


\section{TEMATIKUS TANULMÁNYOK - Digitális szociológia}

percepcióira, attitűdjeire és politikai viselkedésére. E témák fontosságának megítélésében és értékelésében jelentős eltérések mutatkoznak a kormánypárti és ellenzéki szavazók között (Bíró-Nagy 2018, Kmetty 2018, Political Capital 2017). Ez alapján azt mondhatjuk, hogy ezek a kérdések valóban hatással vannak az emberek kognitív és affektív kapacitásaira. Azonban, ahogy arról fentebb volt szó, a közösségi média aktivitást más jellegű egyéni kapacitások, nevezetesen az expresszív, társadalmi és kommunikatív szükségletek motiválják.

A pártok által birtokolt témákkal kapcsolatos visszafogott aktivitás egyfajta telítődési hatásnak is köszönhető lehet. A kampányban a pártok olyan erővel nyomhatják témáikat, hogy azok a választók számára már nem nyújtanak újdonságot, érdekességet és izgalmat. A felhasználók, akik aktivitásaikkal a saját személyes politikai identitásukat akarják megjeleníteni ismerőseik előtt, vagy legalább érdekes és izgalmas tartalmakat mutatni nekik, aligha tudják e célokra felhasználni ezeket a tartalmat. A kormánypárti jelölt migrációval kapcsolatos, vagy az ellenzéki politikus egészségügy állapotával foglalkozó posztja talán nem elég érdekes ahhoz, hogy ismerőseink figyelmébe ajánljuk, vagy akár csak egy lájkra méltassuk. Ez adhat magyarázatot arra is, hogy miért azok a témák népszerűek ezzel szemben, ami éppen a másik oldalhoz kötődnek erőteljesebben: a szokatlan, az általános sztereotípiáknak valamelyest ellentmondó tartalmakhoz való kapcsolódáson keresztül a felhasználó egyedibbnek, érdekesebbnek és szórakoztatóbbnak tűnhet ismerősei előtt.

A pártosabb felhasználók esetén a fordított témagazdag-hatást az is magyarázhatja, hogy a felhasználó be akarja mutatni saját politikai táborának azokkal a témákkal kapcsolatos érveit, amelyek a köztudatban inkább az ellenoldallal kötődnek össze. A Facebook hírvonala meglehetősen heterogén környezet (Barnidge 2017), ahol gyakran ütköznek versengő politikai érvek. Egyirányú kommunikáció esetén megfelelő stratégia lehet a saját témákra fókuszálni, azonban egy erősebb diszkurzivitást mutató nyilvános térben, amelyben számtalan vélemény, kinyilatkoztatás és nyilvánosan látható azonnali reakció zsúfolódik össze, fontosabb szerepe lehet a másik oldal témáira való saját válaszoknak, amelyek ellenérvként szolgálhatnak a politikai viták közösségi oldalakon végtelenül hömpölygő áradatában. A gyakorlat szintjére lefordítva: ha az ellenzéki szavazó számos helyen azt látja, hogy az általa preferált pártok a szabályozatlan migráció pártján állnak, a kormánypárti szavazó pedig gyakran szembesül azzal az érvvel, hogy az Orbán-kormány tönkretette az egészségügyet, akkor különösen vonzó lehet minden olyan tartalom, ami ezekkel az állításokkal vitába száll, és az ellenzék valódi migrációs felfogását vagy éppen az egészségügy fejlődését mutatja be.

A kutatás elméleti kiindulópontjához visszacsatolva, ezek az eredmények öszszességében arra mutatnak rá, hogy különböző egyéni kapacitásokra eltérő politikai tartalmak gyakorolhatnak hatást. Míg a politikai kommunikáció egyes típusai hatékonyak a választók kognícióinak és érzelmeinek alakításában, ugyanezek már hatástalanok lehetnek az expresszivitás és a társas kommunikáció formálásában. Más 


\section{TEMATIKUS TANULMÁNYOK - Digitális szociológia}

szóval: nem ugyanazokról a témákról beszélgetünk, amelyek gondolkodásunkat és érzelmeinket meghatározzák - legalábbis a közösségi média nyilvános terepein. A kormánypárti szavazók számára kétségkívül fontos téma a migráció, és érzelmileg is felkavarja őket a kérdés, a Facebookon mégis jóval kevésbé reagálnak a migrációval foglalkozó üzenetekre. Ha ez a megállapítás helytálló, és különösen, ha igaz a politikai kommunikáció más elemeire is, akkor ez azt is jelenti, hogy a politikai kommunikáció tartalma és formája jelentősen megváltozik a viralizáció trendjének hatására. Azonban több empirikus eredmény szükséges e következtetés levonásához, különösen olyan vizsgálatokra lenne szükség, amelyek a politikai tartalmakra adott kognitív, affektív és expresszív reakciókat hasonlítják össze.

A kutatás limitációjaként említhető meg, hogy a módszer a felhasználói reakciók mögötti motivációk kiszűrésére nem alkalmas: az interakciók mögött „nem őszinte”, azaz politikai érdekek által vezérelt vagy akár politikailag irányított aktivitások is jelen lehetnek. Ugyanakkor a felhasználói reakciók motivációtól függetlenül növelik a vonatkozó tartalmak láthatóságát, ezért az eredmények a viralizáció elmélete szempontjából való jelentőségét ez a korlát kevésbé érinti. Az eredmények interpretációjában továbbá akkor jelenthetnek gondot az irányított felhasználói aktivitások, ha azok szisztematikus mintázatot követnek a vizsgált tényezők tekintetében. Feltételezhetjük azonban, hogy a politikai szereplők leginkább a saját témáik és mobilizációs üzeneteik promotálásában érdekeltek, így amennyiben az ilyen jellegű felhasználók érdemben hatással lennének az eredményeinkre, akkor pozitív témagazda-hatást, és a mobilizációs tartalmak népszerűségét kellett volna találnunk, eredmények azonban éppen ezzel ellentétesek. Felmerülhet az is, hogy az irányított aktivitások az ellenoldal szereplőinek posztjaira fókuszálnak, és egyfajta „trollhatás" állhat a fordított témagazda hatás mögött. Stratégiai szempontból azonban nem ésszerű az ellenoldal láthatóságát éppen a saját témák kapcsán irányított aktivitás segítségével növelni. Ráadásul ez maximum az ellentétes álláspontot közvetlenül a posztnál megjelenített kommentek esetében lehet releváns, viszont a kommentek esetében nem látunk markánsan eltérő mintázatokat a Reakciókhoz és megosztásokhoz képest. Ezen okok miatt okkal feltételezhetjük, hogy a feltárt tendenciák nem irányított aktivitások eredményei.

Bár a tanulmány kutatási dizájnja lehetővé tette a mintavételi döntésekből fakadó korlátok elkerülését, és a hipotéziseket egy kiterjedt és átfogó mintán tesztelte, a kutatás kontextusa még mindig akadályt jelent az eredmények általánosíthatóságával kapcsolatban. Először is, a magyar kontextus meghatározta a vizsgált témákat, hiszen a vizsgált kampány legfontosabb témáira fókuszált a kutatás. Bár ezek nem országspecifikusak, és népszerű kampánytémáknak számítanak szerte a világon, természetesen számos egyéb téma hatását is érdemes vizsgálni. Másodszor, a felhasználói reaktivitás mintázatait az adott kontextus számos egyedi vonása alakíthatja, így a politikai kultúra, a történelem vagy éppen az adott politikai szituáció. Egyetlen országra vonatkozó vizsgáltként ezeket a szempontokat itt nem lehet ki- 


\section{TEMATIKUS TANULMÁNYOK - Digitális szociológia}

szűrni a kutatásból. Nagy szükség van ezért túllépni az egy országra szűkített vizsgálódásokon, és a hipotéziseket több országot lefedő mintán is tesztelni. Végezetül bár a szótár-alapú megközelítés magas érvényességú eredményeket adott, a felügyelt gépi tanulási metódust még érdemes tovább fejleszteni a jövőben.

\section{Irodalom}

Ansolabehere, S. - Iyengar, S. (1994): Riding the Wave and Claiming Ownership Over Issues: The Joint Effects of Advertising and News Coverage in Campaigns. The Public Opinion Quarterly, 58(3), 335-357.

Anspach, N. M. (2017): The New Personal Influence: How Our Facebook Friends Influence the News We Read. Political Communication, 34(4), 590-606.

Banducci, S. - Hanretty, C. (2014): Comparative determinants of horse-race coverage. European Political Science Review, 6(4), 621-640.

Barnidge, M. (2017): Exposure to Political Disagreement in Social Media Versus Face-to-Face and Anonymous Online Settings. Political Communication, 34(2), 302-321.

Baumgartner, F. - Jones, B. D. (1993): Agendas and Instability in American Politics (2nd ed.). University of Chicago Press, Chicago

Bene M. (2020): Virális politika. L'Harmattan, Budapest

Bene M. - Somodi D. (2018): „Mintha lenne saját médiánk...” A kis pártok és a közösségi média. Médiakutató, 19(2), 7-20.

Bennett, W. L. (1990): Toward a Theory of Press-State. Journal of Communication, 103-127.

Bennett, W. L. - Segerberg, A. (2013): The logic of connective action: Digital media and the personalization of contentious politics. Cambridge University Press, New York

Bíró-Nagy A. (2018): Politikai lottóötös: A migráció jelentősége a magyar politikában, 2014-2018. In: Böcskei B. - Szabó A. (szerk.): Várakozások és valóságok. Parlamenti választás 2018. Napvilág Kiadó, MTA TK PTI, Budapest, 269-291.

Blumler, J. G. (1965): Producers' Attitudes towards Television Coverage of an Election Campaign: A Case Study. The Sociological Review, 13(1), 85-115.

Blumler, J. G. (2016): The fourth age of political communication. Politiques de communication, (1), 19-30.

Blumler, J. G. - Kavanagh, D. (1999): The Third Age of Political Communication: Influences and Features. Political Communication, 16(3), 209-230.

Boda Zs. - Sebők M. (szerk.) (2018): A magyar közpolitikai napirend: elméleti alapok, empirikus eredmények. MTA TK Politikatudományi Intézet, Budapest 


\section{TEMATIKUS TANULMÁNYOK - Digitális szociológia}

Bucher, T. (2012): Want to be on the top? Algorithmic power and the threat of invisibility on Facebook. New Media - Society, 14(7), 1164-1180.

Coleman, S. - Blumler, J. G. (2009): The Internet and democratic citizenship: Theory, practice and policy. Cambridge University Press, Cambridge

Dobos G. - Gyulai A. - Horváth A. (2018): Felesleges erőfeszítések? Választási programok és ígéretek 2018-ban. In: Böcskei B. - Szabó A. (szerk.): Várakozások és valóságok. Parlamenti választás 2018. Napvilág Kiadó, MTA TK PTI, Budapest, 317-339.

Dolezal, M. - Zeglovits, E. (2014): Almost an Earthquake: The Austrian Parliamentary Election of 2013. West European Politics, 37(3), 644-652.

Eberl, J. M. - Tolochko, P. - Jost, P. - Heidenreich, T. - Boomgaarden, H. G. (2020): What's in a post? How sentiment and issue salience affect users' emotional reactions on Facebook. Journal of Information Technology \& Politics, 17(1), 48-65.

Ennser-Jedenastik, L. - Gahn, C. - Bodlos, A. - Haselmayer, M. (2021): Does social media enhance party responsiveness? How user engagement shapes parties' issue attention on Facebook. Party Politics, Online First

Ernst, N. - Esser, F. - Blassnig, S. - Engesser, S. (2019): Favorable Opportunity Structures for Populist Communication: Comparing Different Types of Politicians and Issues in Social Media, Television and the Press. The International Journal of Press/Politics, 24(2), 165-188.

Feinerer, I. - Hornik, K. - Meyer, D. (2008): Text Mining Infrastructure in R. Journal of Statistical Software, 25(5), 1-54.

Fournier D. A. - Skaug, H. J. - Ancheta, J. - Ianelli, J. - Magnusson, A. - Maunder, M. Nielsen, A. - Sibert, J. (2012): AD Model Builder: using automatic differentiation for statistical inference of highly parameterized complex nonlinear models. Optimization Methods and Software, 27, 233-249.

Friedman, J. - Hastie, T. - Tibshirani, R. (2010): Regularization Paths for Generalized Linear Models via Coordinate Descent. Journal of Statistical Software, 33(1), $1-22$.

Gerodimos, R. - Justinussen, J. (2015): Obama's 2012 Facebook Campaign: Political Communication in the Age of the Like Button. Journal of Information Technology - Politics, 12(2), 113-132.

Goffman, E. (1959): The Presentation of Self in Everyday Life. Anchor, New York

Guo, L. - Vargo, C. J. - Pan, Z. - Ding, W. - Ishwar, P. (2016): Big Social Data Analytics in Journalism and Mass Communication: Comparing Dictionary-Based Text Analysis and Unsupervised Topic Modeling. Journalism \& Mass Communication Quarterly, 93(2), 332-359. 


\section{TEMATIKUS TANULMÁNYOK - Digitális szociológia}

Heiss, R. - Schmuck, D. - Matthes, J. (2019): What drives interaction in political actors' Facebook posts? Profile and content predictors of user engagement and political actors' reactions. Information, Communication \& Society, 22(10), 14971513.

Iyengar, S. - Peters, M. D. - Kinder, D. R. (1982): Experimental Demonstrations of the "Not-So-Minimal" Consequences of Television News Programs. American Political Science Review, 76(4), 848-858.

Keller, T. R. - Kleinen-von Königslöw, K. (2018): Pseudo-discursive, mobilizing, emotional, and entertaining: Identifying four successful communication styles of political actors on social media during the 2015 Swiss national elections. Journal of Information Technology - Politics, 15(4), 358-377.

Kelm, O. (2020): Why do politicians use Facebook and Twitter the way they do? The influence of perceived audience expectations. SCM Studies in Communication and Media, 9(1), 8-34.

Klinger, U. - Russmann, U. (2017): „Beer is more efficient than social media” - Political parties and strategic communication in Austrian and Swiss national elections. Journal of Information Technology \& Politics, 14(4), 299-313.

Klinger, U. - Svensson, J. (2015): The emergence of network media logic in political communication: A theoretical approach. New Media \& Society, 17(8), 1241-1257.

Kmetty Z. (2018): Korrupció percepciója, pártosság, választási részvétel: Hogyan változott a szavazók véleménye a hazai politikai korrupcióról a 2014-2018-as parlamenti ciklus alatt? In: Böcskei B. - Szabó A. (szerk.): Várakozások és valóságok. Parlamenti választás 2018. Napvilág Kiadó, MTA TK PTI, Budapest

Kreiss, D. (2016): Prototype Politics: Technology-Intensive Campaigning and the Data of Democracy. Oxford University Press, New York

Kruikemeier, S. - Gattermann, K. - Vliegenthart, R. (2018): Understanding the dynamics of politicians' visibility in traditional and social media. The Information Society, 34(4), 215-228.

Kuhn, M. (2008): Building Predictive Models in R Using the caret Package. Journal of Statistical Software, 28(5), 1 - 26.

Kwartler, T. (2017): Text Mining in Practice with R. Wiley, Hoboken

Lundby, K. (ed.). (2009): Mediatization: Concept, Changes, Consequences.Peter Lang Inc., International Academic Publishers, New York

McCombs, M. E. - Shaw, D. L. (1972): The Agenda-Setting Function of Mass Media. The Public Opinion Quarterly, 36(2), 176-187.

McGregor, S. C. (2020): „Taking the Temperature of the Room”: How Political Campaigns Use Social Media to Understand and Represent Public Opinion. Public Opinion Quarterly, 84(S1), 236-256. 


\section{TEMATIKUS TANULMÁNYOK - Digitális szociológia}

Mudde, C. (2004): The Populist Zeitgeist. In: Government and Opposition, 39(4), 541-563.

Muddiman, A. - McGregor, S. C. - Stroud, N. J. (2019): (Re) claiming our expertise: Parsing large text corpora with manually validated and organic dictionaries. Political Communication, 36(2), 214-226.

Petrocik, J. R. (1996): Issue Ownership in Presidential Elections, with a 1980 Case Study. American Journal of Political Science, 40(3), 825-850.

Political Capital (2017): Gyógyítható-e az egészségügy? Friedrich Ebert Stiftung, Budapest

Robin, X. - Turck, N. - Hainard, A. - Tibertim N. - Lisacek, F. - Sanchez, J. - Müller, M. (2011): pROC: an open-source package for R and S+ to analyze and compare ROC curves. BMC Bioinformatics, 12, 77.

Sahly, A. - Shao, C. - Kwon, K. H. (2019): Social Media for Political Campaigns: An Examination of Trump's and Clinton's Frame Building and Its Effect on Audience Engagement. Social Media + Society, 5(2).

Sebők M. (szerk.) (2016): Kvantitatív szövegelemzés és szövegbányászat a politikatudományban. L'Harmattan, Budapest

Staender, A. - Ernst, N. - Steppat, D. (2019): Was steigert die Facebook-Resonanz? Eine Analyse der Likes, Shares und Comments im Schweizer Wahlkampf 2015. Studies in Communication and Media, 8(2), 236-271.

Štětka, V. - Surowiec, P. - Mazák, J. (2019): Facebook as an instrument of election campaigning and voters' engagement: Comparing Czechia and Poland. European Journal of Communication, 34(2), 121-141.

Strömbäck, J. (2008): Four Phases of Mediatization: An Analysis of the Mediatization of Politics. The International Journal of Press/Politics, 13(3), 228-246.

Strömbäck, J. - Esser, F. (2014): Introduction. Journalism Studies, 15(3), 243-255.

Svensson, J. (2011): The Expressive Turn of Citizenship in Digital Late Modernity. JeDEM - EJournal of E-Democracy and Open Government, 3(1), 42-56.

Turcotte, J. - York, C. - Irving, J. - Scholl, R. M. - Pingree, R. J. (2015): News Recommendations from Social Media Opinion Leaders: Effects on Media Trust and Information Seeking. Journal of Computer-Mediated Communication, 20(5), 520-535.

Xenos, M. A. - Macafee, T. - Pole, A. (2017): Understanding variations in user response to social media campaigns: A study of Facebook posts in the 2010 US elections. New Media - Society, 19(6), 826-842. 